\title{
The PERK-Dependent Molecular Mechanisms as a Novel Therapeutic Target for Neurodegenerative Diseases
}

\author{
Wioletta Rozpędek-Kamińska ${ }^{1}$, Natalia Siwecka ${ }^{1}$, Adam Wawrzynkiewicz ${ }^{1}$, \\ Radosław Wojtczak ${ }^{1}$, Dariusz Pytel ${ }^{2}$, J. Alan Diehl ${ }^{2}$ and Ireneusz Majsterek ${ }^{1, *}$ \\ 1 Department of Clinical Chemistry and Biochemistry, Medical University of Lodz, 90-419 Lodz, Poland; \\ wioletta.rozpedek@umed.lodz.pl (W.R.-K.); natalia.siwecka@stud.umed.lodz.pl (N.S.); \\ adam.wawrzynkiewicz@stud.umed.lodz.pl (A.W.); radoslaw.wojtczak@p.lodz.pl (R.W.) \\ 2 Department of Biochemistry and Molecular Biology, Hollings Cancer Center, Medical University of South \\ Carolina, Charleston, SC 29425, USA; pytel@musc.edu (D.P.); jad283@case.edu (J.A.D.) \\ * Correspondence: ireneusz.majsterek@umed.lodz.pl; Tel.: +48-42-272-53-00
}

Received: 14 February 2020; Accepted: 17 March 2020; Published: 19 March 2020

\begin{abstract}
Higher prevalence of neurodegenerative diseases is strictly connected with progressive aging of the world population. Interestingly, a broad range of age-related, neurodegenerative diseases is characterized by a common pathological mechanism-accumulation of misfolded and unfolded proteins within the cells. Under certain circumstances, such protein aggregates may evoke endoplasmic reticulum (ER) stress conditions and subsequent activation of the unfolded protein response (UPR) signaling pathways via the protein kinase RNA-like endoplasmic reticulum kinase (PERK)-dependent manner. Under mild to moderate ER stress, UPR has a pro-adaptive role. However, severe or long-termed ER stress conditions directly evoke shift of the UPR toward its pro-apoptotic branch, which is considered to be a possible cause of neurodegeneration. To this day, there is no effective cure for Alzheimer's disease (AD), Parkinson's disease (PD), Huntington's disease (HD), or prion disease. Currently available treatment approaches for these diseases are only symptomatic and cannot affect the disease progression. Treatment strategies, currently under detailed research, include inhibition of the PERK-dependent UPR signaling branches. The newest data have reported that the use of small-molecule inhibitors of the PERK-mediated signaling branches may contribute to the development of a novel, ground-breaking therapeutic approach for neurodegeneration. In this review, we critically describe all the aspects associated with such targeted therapy against neurodegenerative proteopathies.
\end{abstract}

Keywords: neurodegenerative diseases; neurodegeneration; Alzheimer's disease; Parkinson's disease; PERK; endoplasmic reticulum stress; unfolded protein response; apoptosis; PERK inhibitors

\section{Introduction}

Neurodegeneration is generally defined as progressive, irreversible loss of neurons, which may affect either the peripheral or central nervous system (CNS). There are numerous risk factors for neurodegenerative diseases, which include genetic polymorphisms, gender, poor education, oxidative stress, hypertension, inflammation, depression, stroke, tumors, diabetes, vitamin deficiency, immune and metabolic conditions, and frequent exposure to chemical agents, but among them the primary risk factor constitutes the increasing age of the world population [1]. Nowadays, almost every country in the world experiences a progressive increase in number of elderly people in their population. According to the global statistics by United Nations, in 2019 there were 703 million people aged 65 years or over, which has nearly doubled as compared to 1990 , from $6 \%$ to $9 \%$ overall. It is also estimated 
that this number will rise further and that it will have doubled to 1.5 billion by 2050 (16\%), which means that by this time one in six people will be aged 65 years and above. Currently, individuals 80 years and older are the fastest growing segment of the worldwide population [2].

Dementia, a clinical syndrome intrinsically linked to both aging and major neurodegenerative diseases, is an overall term that refers to loss of mental abilities. It covers a broad range of symptoms strictly associated with a significant decline in memory and aggravation of cognitive function [3]. Globally, $1-6 \%$ of the human population over 65 years old and $10-20 \%$ of those over 80 years old suffer from dementia [4]. The newest data have reported that due to the rapid aging of the world population, the incidence of dementia may significantly increase to approximately 65 million before 2030 and 115 million before 2050 [5]. Dementia constitutes a serious public health problem, as every four seconds one new case of dementia is diagnosed, resulting in 7.7 million cases per year [6].

Most of the neurodegenerative diseases, including Alzheimer's disease (AD), Parkinson's disease (PD), Huntington's disease (HD), and prion disease, are closely correlated with the aggregation of the pathological proteins within the nervous tissue. This event constitutes the main hallmark of the neurodegenerative processes at the molecular level. Protein aggregates comprise structures composed of pathological unfolded or misfolded proteins such as $\alpha$-synuclein ( $\alpha$-syn) in PD, amyloid $\beta$ (A $\beta$ ) or tau protein in $\mathrm{AD}$, mutant huntingtin protein $(\mathrm{mHtt})$ in $\mathrm{HD}$, as well as prion protein $(\mathrm{PrP})$ in transmissible prion encephalopathies $[7,8]$.

The majority of currently used treatments against the aforementioned neurodegenerative disorders may only alleviate symptoms and slow down progression of the disease, whereas the newest experimental research, in in vitro and in vivo models, has demonstrated a promising opportunity of pathogenic therapy for neurodegenerative diseases based on deuterium-reinforced polyunsaturated fatty acid (D-PUFA) administration. It has been reported that oxidative damage resulting from increased oxidative stress constitutes a critical factor in the development and progression of neurodegenerative diseases, including AD, PD, HD, as well as renal diseases. Interestingly, oxidative damage accompanies all AD stages, and thereby it plays a key role in AD pathogenesis. D-PUFAs, in comparison with regular hydrogenated PUFAs (H-PUFAs), are prominently more resistant to the reactive oxygen species (ROS)-mediated chain reaction of lipid peroxidation (LPO). A study by Elharram et al. has demonstrated that, in an oxidative stress-dependent mouse model of age-related cognitive impairment with AD-like biochemical and structural pathologies with deletion of the aldehyde dehydrogenease 2 gene $\left(\right.$ Aldh $\left.2^{-\digamma}\right)$, treatment with D-PUFAs for 18 weeks evoked an approximate $55 \%$ decrease of F2-isoprostanes ( $\mathrm{F}_{2}$-IsoPs) and $20-25 \%$ decrease of prostaglandin $\mathrm{F}_{2 \alpha}\left(\mathrm{PGF}_{2 \alpha}\right)$ in both the cortex and hippocampus, as compared to H-PUFA-treated Aldh2 ${ }^{-/-}$mice for 18 weeks. Hence, this aforementioned study indicated that D-PUFAs significantly reduce LPO brain products in an Aldh2 ${ }^{--}$mouse model of sporadic AD. Moreover, a study by Elharram et al. has also shown that Aldh2 ${ }^{-\digamma}$ mice fed a Western-type diet enriched with D-PUFAs exhibited better results in cognitive/memory tests, significantly resetting results of the Aldh $2^{--}$mice fed a diet enriched with D-PUFAs to that of wildtype mice fed a typical laboratory diet. Thereby, a study by Elharram et al. has indicated that D-PUFAs may constitute a novel treatment strategy against AD, resulting in significant reduction of LPO and cognitive/memory decline in $\mathrm{AD}$ individuals [9]. Another study by Raefsky et al. has reported that D-PUFAs may enter the brain and subsequently incorporate into membrane lipids directly leading to suppression of neuronal lipid peroxidation. It has been demonstrated that deuterium was incorporated into docosahexaenoic acid (DHA) and arachidonic acid (ARA) in the hippocampus and cerebral cortex in amyloid precursor protein (APP)/presenilin-1 (PS1) double mutant transgenic mice fed a D-PUFA diet, as well as the D-PUFA diet being strictly correlated with significant decrease in products of LPO, including both $\mathrm{F}_{2}$-IsoPs and F4-neuroprostanes, in brain tissue of the mouse model of AD. Furthermore, as compared to AD mice on a H-PUFA diet, in AD mice on a D-PUFA diet the levels of $A \beta_{40}$ and $A \beta_{38}$ in the hippocampus were markedly reduced, with a trend to decreased concentrations of $A \beta_{42}$ [10]. Oxidative stress plays a crucial role not only in the pathogenesis of $\mathrm{AD}$, but also $\mathrm{PD}$, as there is ample evidence that PUFA peroxidation products have been found in post-mortem tissue from PD individuals. Interestingly, study by Shchepinov et al. has 
reported that deuteration of bisallylic sites of PUFAs may trigger partial protection against nigrostriatal dopaminergic pathway failure in 1-methyl-4-phenyl-1,2,3,6-tetrahydropyridine (MPTP)-treated mice, which represent a mouse model of oxidative stress and cell death. It has been demonstrated that mice fed a H-PUFA diet, after MPTP exposure, exhibited a 78.7\% loss of dopamine and a $64.3 \%$ loss of dopamine metabolite 3,4-dihydroxyphenylacetic acid (DOPAC), whereas, in the same experimental model, mice fed a H-PUFA diet exhibited only a $46.8 \%$ loss of dopaminergic (DA) and $36.5 \%$ loss of DOPAC. After MPTP treatment, D-PUFA-supplemented mice demonstrated higher levels of striatal tyrosine hydroxylase (TH) immunoreactivity than in H-PUFA-supplemented mice, which also indicates a neuroprotective role of D-PUFAs. Moreover, following MPTP treatment, a markedly higher number of nigral dopaminergic neurons have been indicated in the D-PUFA-supplemented mice in comparison with H-PUFA-supplemented mice. Thus, the above-mentioned research has demonstrated that deuteration of PUFAs may significantly slow oxidative cellular damage and constitute a modification of PD course [11]. As previously mentioned, oxidative damage also constitutes a key factor in the HD pathogenesis. Biomarkers of excessive LPO have been found both in mouse models of HD and HD individuals. Thereby, reduction of LPO may constitute a promising treatment strategy against HD. A study by Hatami et al. has demonstrated that Q140 knock-in (Q140 KI) mice, which represent a mouse model of HD, fed a diet enriched in D-PUFAs exhibited markedly decreased level of $\mathrm{F}_{2}$-IsoPs in the striatal tissue by approximately $80 \%$ as compared to H-PUFA-supplemented Q140 KI mice, suggesting that D-PUFAs relevantly decrease LPO in a mouse model of HD. Moreover, D-PUFA treatment mitigates cognitive impairment in Q140 KI mice, as after 5 months of consumption of a diet enriched in deuterium there was found to be significantly improved performance in novel object recognition tests, without changing motor deficits and accumulation of huntingtin protein (Htt). Hence, after further detailed investigations, D-PUFA administration may constitute a novel treatment strategy against HD [12].

Moreover, recent studies have indicated that pathogenesis of neurodegenerative diseases may be correlated not only with oxidative stress, but also with a significant alteration in protein homeostasis within the lumen of the endoplasmic reticulum (ER), which evokes the ER stress conditions. As the subsequent molecular event, the protein kinase RNA-like endoplasmic reticulum kinase (PERK)-dependent unfolded protein response (UPR) signaling pathways, which play a key role in memory and neurodegeneration, are directly activated [13]. Interestingly, the UPR is characterized by both a pro-adaptive and pro-apoptotic role. The newest data have indicated that under severe or long-term ER stress conditions, the pro-apoptotic branch of the UPR is activated, resulting in neuronal cell death. Thus, inhibition of the PERK-mediated, pro-apoptotic UPR signaling branches on the molecular level may also contribute to the development of a novel, targeted treatment strategy against neurodegeneration [14].

\section{Alzheimer's Disease}

Among a broad range of neurodegenerative diseases, AD constitutes $60-70 \%$ of all types of dementia [15]. Of the world population, 26.6 million were affected by AD in 2006, but currently it is expected that the AD prevalence may quadruple by 2050; thus, 1 in 85 persons will suffer from AD [16]. Nowadays, the AD prevalence is approximately $5 \%$ in people aged over 65 years old, but it significantly increases up to $20 \%$ in the group of people over 85 years of age [5]. On the basis of the age of onset, $\mathrm{AD}$ is clinically divided into two types: early-onset $\mathrm{AD}$ (EOAD) and late-onset $\mathrm{AD}$ (LOAD). The Dementia Mutation Database indicates that approximately 300 mutations in presenilin-1 (PS1) and presenilin-2 (PS2) and 635 mutations in amyloid precursor protein (APP) constitute causative factors for EOAD development [17]. EOAD is characterized as developing in individuals before age 65, whereas LOAD shows symptoms in individuals after age 65. The majority of cases of familial AD (FAD) are strictly correlated with EOAD, and they account for only $5-10 \%$ of all AD cases. Thereby, sporadic cases of AD mostly present LOAD and constitute 90-95\% of all AD cases [18]. 
$\mathrm{AD}$ is an age-related, progressive, neurodegenerative disease of the CNS, characterized by rapid progression of memory loss and significant impairment of multiple cognitive functions [19]. There are three general stages of $\mathrm{AD}$ : mild, moderate, and severe [20]. The time course of AD averages about 7-10 years. Impaired recent memory and other cognitive dysfunctions such as executive dysfunction, including concentration and problem solving abilities, constitute one of the first symptoms of AD. Progression of $\mathrm{AD}$ is strictly correlated with language and visuospatial impairment, as well as significant personality changes. The early stage of AD lasts $2-5$ years, whilst the moderate stage $2-4$ years and it finally leads to mental and physical disability and death at the late stage [21,22]. The main hallmarks of $\mathrm{AD}$ are extracellular deposition of senile plaques and intracellular aggregation of neurofibrillary tangles (NFTs) within the brain tissue [23]. The above-mentioned pathological aggregates constitute the primary biomarkers for AD diagnosis [24]. Senile plaques are mainly composed of the pathological form of $A \beta$, whereas the major component of NFTs is the hyperphosphorylated form of tau protein $[25,26]$. Numerous hypotheses regarding the AD etiology have been presented, but the AD pathogenesis still remains not fully understood [27]. Pathological changes within the brain tissue during the early stages of AD start in the entorhinal cortex and hippocampus. They are subsequently spread into the temporal, parietal, and frontal association cortices. At the early stages of $\mathrm{AD}$, significant neurodegeneration occurs in poorly myelinated limbic neurons in the hippocampus and association cortex, directly related to memory and learning. Degeneration of highly myelinated neurons occurs only during the final phases of $\mathrm{AD}$ [28].

High content of PUFAs and transition metals within the brain tissue as well as high oxygen utilization and reduced antioxidant defense provide an environment susceptible to oxidative damage that is strictly correlated with the early stages of AD. ROS-mediated non-enzymatic LPO of PUFAs constitute a primary factor contributing to oxidative damage directly leading to altered membrane fluidity and significant changes in membrane-bound enzymes and receptors. ROS-initiated LPO of PUFAs begins by abstraction of bis-allylic hydrogens resulting in resonance-stabilized free radicals generation, which may react with molecular oxygen and finally form lipid peroxyls. Peroxyls abstract a hydrogen atom off an adjacent PUFA molecule, thus they play a crucial role in propagation of chain reaction. LPO leads to the creation of byproducts derived through either endoperoxide or hydroperoxide intermediates, decomposition of which results in creation of reactive aldehydes including among others: malondialdehyde, acrolein, 4-hydroxynonenal (HNE), and 4-hydroxyhexenal (HHE) [9]. Thereby, the progressive neurodegeneration process in AD is closely correlated not only with excessive deposition of $\mathrm{A} \beta$, but also with oxidative stress and disruption of $\mathrm{Ca}^{2+}$ homeostasis, which subsequently trigger hyperexcitability and excitotoxicity of the neuronal network. It has been demonstrated that brain tissue is characterized by a high content of PUFAs such as ARA, DHA, and eicosapentaenoic acid (EPA) that are produced from linoleic acid and linolenic acid, which are susceptible to ROS attack directly leading to LPO. The above-mentioned molecular event results in significant membrane PUFA damage; generation of F2, F3, and F4 isoprostanes; and highly reactive HNE and HHE. There is ample evidence that oxidative stress and LPO play a crucial role in synaptic dysfunction and neurodegeneration in AD. It has been revealed that HNE evokes disruption of $\mathrm{Ca}^{2+}$ homeostasis and energy metabolism, directly leading to neuronal apoptosis in AD course [10].

Aggregation of misfolded and unfolded pathological proteins, occurrence of oxidative stress, and multiple metabolic disturbances inside the neurons of brain tissue represent the characteristic hallmarks of $\mathrm{AD}$ [29]. Currently, due to insufficient treatment strategies against AD, which are only symptomatic, novel therapeutic strategies based on inhibition of PERK-dependent signaling branches are under detailed investigation [30].

The main hallmark of $\mathrm{AD}$ brains constitutes deposition of insoluble senile plaques mainly composed of a longer, pathological form of $A \beta$ composed of 42 amino acids $\left(A \beta_{42}\right)$ [31]. There is ample evidence that level of $A \beta_{42}$ is significantly increased in $A D$ brains due to its elevated hydrophobicity, which may facilitate its oligomerization and subsequent deposition in the form of toxic senile plaques among neurons of $\mathrm{AD}$ brain tissue [32]. $\mathrm{A} \beta$ is directly generated via proteolytic cleavage of the APP 
by three secretases: $\alpha, \beta$, and $\gamma$ [33]. APP constitutes a transmembrane protein, expression of which occurs in multiple cell types including neurons [34]. The APP gene on chromosome 21 has three most common isoforms: APP695, APP751, and APP770, whereas only the APP695 is predominantly expressed in the CNS [35]. It has been reported that there are 32 APP, 179 PS1, and 14 PS2 gene mutations directly leading to deposition of senile plaques within the brain tissue, thus development of autosomal dominant EOAD [35]. APP mutations at the cleavage sites for APP processing via secretases $\beta$ and $\gamma$ result in increased A $\beta$ generation into the luminal/extracellular compartment [36]. PS1 and PS2 act as a component of $\gamma$-secretase catalytic subunit [37]. There is a plethora of in vitro and in vivo studies, which have demonstrated that PS1 and PS2 mutations markedly increase generation of A $\beta$ and the ratio of $A \beta_{42}$ to $A \beta_{40}$ [38].

APP processing occurs through two distinct pathways: non-amyloidogenic or amyloidogenic [39]. Non-amyloidogenic APP processing occurs under physiological conditions with activation of $\alpha$ and $\gamma$ secretases [40]. $\alpha$-Secretase, to prevent A $\beta$ generation, cleaves APP between Lys ${ }^{16}$ and $\mathrm{Leu}^{17}$ within the $\mathrm{A} \beta$ sequence, resulting in generation of soluble $\mathrm{APPs}_{\alpha}$ and membrane-bound $\mathrm{C} 83$ fragments. Afterwards, C83 is cleaved in the $\gamma$-secretase-dependent manner into the APP intracellular domain (AICD) and p3 fragments. Function of p3 still remains unclear, whereas AICD may create a complex with several factors including stabilizing factor Fe65 and act as a transcription factor of a broad range of genes, including neprilysin (NEP), which enhances $A \beta$ degradation [41]. Alternatively, under pathological conditions, in the APP cleavage via the amyloidogenic pathway the central role is played by $\beta$ and $\gamma$ secretases. $\beta$-Secretase cleaves APP at the Asp ${ }^{1}$ site, which releases two products: soluble ectodomain $\mathrm{APPs}_{\beta}$ and C-terminal fragment C99. C99 is subsequently cleaved by $\gamma$-secretase into AICD and 39-42 amino acid $A \beta$, which promote formation of senile plaques among neurons of brain tissue [42]. $\gamma$-Secretase-mediated processing of $C 99$ generates both $A \beta_{42}$ and $A \beta_{40}$, which may constitute a components of neuritic plaques, but $A \beta_{42}$, as compared to $A \beta_{40}$, is characterized by higher neurotoxicity and aggregation ability [43].

In the pathogenesis of $\mathrm{AD}$, enhanced expression of $\beta$-secretase, the major factor that promotes accumulation of pathological senile plaques within the nervous tissue, directly leads to neuronal loss, synaptic failure, and significant reduction of brain volume, resulting in memory deficits and impairment of cognitive function. Several studies have confirmed the overexpression of BACE1, encoding for $\beta$-secretase or $\beta$-site amyloid precursor protein cleaving enzyme 1 (BACE1), in brain tissue samples obtained from AD patients, together with other hallmarks of AD pathology [44-46]. Numerous data have indicated a significantly elevated level of $\beta$-secretase in post-mortem AD brains. Moreover, overexpression of both $\beta$-secretase and phosphorylated form of the translation initiation factor $2 \alpha$ (p-eIF2 $\alpha$ ), which constitutes the main substrate of PERK, was observed in mouse model of amyloid deposition expressed five familial AD (FAD) mutations (5XFAD) [47]. Both phosphorylated form of PERK (p-PERK) and p-eIF2 $\alpha$ levels were markedly increased in hippocampal neurons of AD brains [48]. Moreover, Stutzbach et al. found elevated levels of p-PERK and p-eIF2 $\alpha$ in the hippocampal pyramidal cells and in the frontal cortex [49]. Interestingly, overactivation of cytosine-cytosine-adenosine-adenosine-thymidine (CCAAT)/-enhancer-binding protein homologous protein (CHOP), another PERK downstream target, has been recently found to be strictly associated with the occurrence of all hallmarks of $\mathrm{AD}$. Upregulation of $\mathrm{CHOP}$ resulted in the following sequence of events: generation of ROS, oxidative damage, high level of $A \beta$, perturbation in iron homeostasis, neuroinflammation, and eventually neuronal cell death via apoptosis [50].

However, on the basis of data from the other sources, the involvement of PERK-dependent UPR signaling pathway in the process of both AD-related amyloidogenesis and tauopathy is still debatable. According to the study by Sadleir et al., 5XFAD transgenic mice with the enhanced expression of APP and PS1 do not exhibit activation of ER stress conditions nor activation of UPR signaling. The levels of UPR-related proteins such as chaperone binding immunoglobulin protein (BiP), phosphorylated inositol-requiring enzyme 1 (p-IRE1 $\alpha$ ), p-eIF2 $\alpha$, activating transcription factor 4 (ATF4), or CHOP in $\mathrm{AD}$ mouse model were not significantly elevated as compared to the non-transgenic control mice. 
Interestingly, the experiment has also been performed in 5XFAD mice with silenced BACE1 expression with similar results. These results imply that ER stress might not be the specific hallmark of AD, or at least is not induced by overexpression of APP and PS1 [51]. A separate study by Spatara et al. has proven that the activation of the UPR signaling pathway is absent in several models of tauopathies such as the SH-SY5Y cell line, 4R tau- and P301L tau-expressing HEK293 cells, or PS19 transgenic mice [52]. These theory is supported by another piece of evidence that was provided by Pitera et al. In their study, no activation of UPR was reported in a rTg4510 mouse model that shared the expression of mutant tauP301L as well as in the primary hippocampal neurons of E15-E18 C57Bl/6 mice [53].

Currently used treatment modalities are symptomatic and may only temporarily alleviate problems with memory and cognitive function. Furthermore, the clinical effect of currently used treatments against $\mathrm{AD}$ is modest, thereby development of novel, targeted treatment strategies may solve problems connected with AD treatment. For instance, the newest data have reported that fine-tuning of the eIF2 $\alpha$ phosphorylation may play a key role in controlling mnemonic processing. It has been demonstrated that a decreased level of the eIF2 $\alpha$ phosphorylation directly evokes enhanced long-term memory consolidation and synaptic plasticity, whereas enhanced phosphorylation of the eIF2 $\alpha$ causes their impairments. Thereby, genetic and pharmacological manipulations of the eIF $2 \alpha$ phosphorylation on learning and memory processes are currently under detailed investigation [54].

\section{Parkinson's Disease}

PD constitutes the second most common neurodegenerative disease after $\mathrm{AD}$, with over 6 million people affected worldwide in 2016, but it is considered the fastest growing in terms of prevalence, disability, and mortality [55]. The number of individuals suffering from PD more than doubled from 1990 to 2016, and this amount is projected to progressively increase up to 9 million by 2030 [56] due to the aging society and high sociodemographic index [55]. PD is generally characterized by two major hallmarks: selective loss of dopaminergic (DA) neurons in substantia nigra pars compacta (SNpc) and accumulation of $\alpha$-syn aggregates called Lewy bodies, which are sufficient to confirm the diagnosis in idiopathic forms of the disease [57]. However, the actual cause of neurodegeneration in PD still remains unclear due to its complexity, and thus it needs to be further elucidated. Nowadays, the pathogenesis of PD is considered multifactorial and connected with proteasome inhibition, impaired vesicle trafficking, alterations in calcium regulation, and mitochondria and lysosome dysfunction, all of which trigger oxidative stress within DA neurons [58,59].

PD is certainly age-related, as its incidence sharply increases with age and it becomes even 5- to 10 -fold higher among individuals over the age of 60 [57]. Currently, the disease onset is estimated between 65 to 70 years of age, whereas its morbidity rates to a peak around age of $85-89$ [60]. The other major risk factors may be divided into endogenous, which include, among others, gene mutations or history of melanoma, as well as exogenous, such as toxic exposure, traumatic brain injuries (TBI), and some dietary habits [61]. Overall, there have been 26 genes implicated in PD pathogenesis identified, although it is considered that environmental factors are more common causes of PD onset [61,62]. Among genes most frequently associated with PD, leucine-rich repeat kinase 2 (LRRK2), synuclein alpha (SNCA), vacuolar protein sorting-associated protein 35 (VPS35), and glucosylceramidase beta (GBA) can be indicated, mutations of which occur in autosomal dominant PD (ADPD), as well as parkin RBR E3 ubiquitin protein ligase (Parkin), pten-induced putative kinase 1 (PINK1), and protein deglycase (DJ1), linked to early-onset autosomal recessive PD (ARPD) [57,62]. In general, SNCA encodes for $\alpha$-syn, whereas the other above-mentioned genes are involved in autophagy, mitochondria metabolism, proteostasis, and chaperoning, all of which are deregulated in PD [63,64]. On the contrary, metabolic products of a drug called MPTP, as well as rotenone and some other pesticides, were confirmed to cause an acquired form of PD via interfering with the redox balance within midbrain neurons $[65,66]$. Both TBI and mild traumatic brain injury (MTBI) may contribute to development of PD due to disruption of the blood-brain barrier (BBB), subsequent induction of neuroinflammation, glutamate release, mitochondrial dysfunction, and eventually accumulation of $\alpha$-syn $[67,68]$. 
Bradykinesia, resting tremor, postural instability, and muscular rigidity represent the specific symptoms of $\mathrm{PD}$, which are connected with degeneration of DA neurons and thus result in neurotransmission failure within the nigrostriatal pathway $[64,66,69]$. Due to neural plasticity, it is estimated that a significant amount of DA neurons (approximately 30\%) must have already been damaged by the time of the occurrence of the symptoms $[66,70,71]$. Other common extrapyramidal motor disturbances that have been noted among PD patients include muscle stiffness, motor blocks (freezing), akinesia, mask-like face expression, flexed posture, irregular arm swing, abnormal gait, and balance impairment [72,73]. Autonomic function may also be disturbed and it is commonly manifested by gastrointestinal motility disorders (e.g., constipation), urinary incontinence, orthostatic hypotension, or sexual dysfunction $[64,72,74,75]$. Symptoms such as cognitive decline, anxiety, depression, and other behavioral or sleep disorders are also frequently observed in PD sufferers [64,76,77]. In general, non-motor features usually occur many years prior to the motor symptoms' onset [64,77], among which the olfactory loss (hyposmia or anosmia) is regarded as the most relevant early sign of PD, although being frequently overlooked [78]. All of the above-mentioned symptoms worsen with age, significantly decrease the quality of life in patients by impairing their daily functioning, and eventually lead to permanent disability.

Although many therapeutic options are available for PD treatment nowadays, none of them are considered flawless, nor do they provide full recovery. In most cases, despite alleviation of the symptoms, the progression of the disease cannot be affected. Moreover, in view of the recently reported drug resistance, it becomes even more complicated to deter the disease progression.

The neurons of the substantia nigra (SN) region are, among other cell types, particularly susceptible to metabolic and oxidative stress. Indeed, a study by Floor et al. found that SN contained twice as many oxidized proteins as other regions of post-mortem brains in healthy individuals [79]. This is not surprising in light of the fact that $\mathrm{SN}$ neurons possess particularly long, unmyelinated axons; numerous synapses; as well as exhibit autonomous, altered calcium metabolism, all of which require substantial energy [66]. On the other hand, it has been confirmed that DA neurons have decreased levels of two major antioxidant defense agents: ferritin, which links iron ions and stores them in a non-toxic form, and glutathione, the main ROS scavenger. Conversely, they contain increased amounts of neuromelanin pigment, free iron ions, and dopamine with its metabolites, all of which are capable of induction of ROS $[65,80]$.

$\alpha$-Syn is a small (14 kDA, 140 amino acids), soluble protein encoded by the SNCA gene [66,81]. To date, multiplications of SNCA as well as six missense mutations (particularly A30P, A53T, and E46K) have been identified in familial forms of PD [66,82]. It has been found that $\alpha$-syn levels correlate with PD onset, as duplication of SNCA resulted in late-onset ADPD, whereas triplication resulted in early onset PD [83]. The presence of $\alpha$-syn is observed, apart from in PD, in a wide spectrum of other neurodegenerative disorders, such as dementia with Lewy bodies (DLB), PD with dementia (PDD), pure autonomic failure (PAF), or multiple system atrophy (MSA), commonly referred to as alpha-synucleinopathies $[65,84] . \alpha$-Syn is abundantly expressed in the brain (estimated at about $1 \%$ of all cytosolic proteins), where it is localized in presynaptic membranes and vessicles to maintain neurotransmission and synaptic plasticity $[74,82,84]$. Moreover, expression of SNCA has recently been associated with iron and redox metabolism, both on transcriptional and post-transcriptional level [65].

Monomers and tetramers constitute the physiological forms of $\alpha$-syn, whereas oligomers and fibrils constitute the pathogenic forms [66], among which the oligomeric species are considered the most harmful [85]. Structurally, the $\alpha$-syn monomer contains three structural regions: the $\mathrm{N}$-terminal domain (1-60) with a multi-repeated consensus sequence (KTKEGV), the central domain (61-95) or the non-amyloid-beta component (NAC) with highly hydrophobic motif, and the C-terminal domain (96-140) with acidic proline residues $[64,69,81]$. The central NAC domain, highly amyloidogenic, is normally protected by charges of $\mathrm{N}$ - and C-terminal regions, thus perturbations of this interaction (e.g., in case of mutations) may contribute to $\alpha$-syn aggregation [86]. $\alpha$-Syn monomers may undergo conformational changes and self-assemble into oligomeric species under appropriate conditions, such 
as the above-mentioned mutations, oxidative stress caused by 4-hyroxy-2-nonenal, cytochrome c or $\mathrm{H}_{2} \mathrm{O}_{2}$ release, as well as post-translational modifications, which cause the change of conformation from $\alpha$-helix to $\beta$-sheet $[72,74,85]$. Misfolded $\alpha$-syn becomes in turn progressively insoluble and accumulates in the form of intracellular inclusions in neuronal somas called Lewy bodies (LBs) or dendrites and axons as Lewy neurites (LNs) [70,87]. LBs are highly organized, spherical aggregates composed of insoluble eosinophilic amyloid surrounded by ubiquitinated $\alpha$-syn fibrils abnormally phosphorylated at Ser129 [64,88]. Accumulation of LBs induces widespread toxicity within various cellular organelles, impairs numerous cellular functions such as formation of soluble NSF attachment protein receptor (SNARE) complex, dopamine neurotransmission and synaptic-vesicle motility, and eventually leads to neurodegeneration of DA neurons $[64,89]$. The decline in proteolytic defense mechanisms, which is intrinsically connected with increasing age, causes disturbances in autophagy-lysosomal and ubiquitin-proteasome systems, both of which are involved in maintenance of $\alpha$-syn proteostasis [57]. In effect, the mutant forms of $\alpha$-syn cannot be efficiently degraded by protein clearance mechanisms, and hence they disrupt loading and clearance of the other cargoes, resulting in a vicious cycle [72]. Interestingly, both increased levels of wild-type $\alpha$-syn and presence of its abnormal forms have been proven to accelerate the accumulation process [64]. Such $\alpha$-syn aggregates subsequently propagate through interconnected circuits of the brain in a prion-like mechanism, and the spreading closely correlates with the disease progression [82].

Numerous data have demonstrated that oxidative stress plays a crucial role in PD pathogenesis. Oxidized PUFAs may evoke a disruption of cellular homeostasis via oxidation of DNA, proteins, and other cellular targets such as $\alpha$-syn and dopamine. PUFAs constitute a key component of lipid membranes as well as early targets of ROS-mediated oxidation, which negatively affects membrane properties such as fluidity. Moreover, oxidized PUFAs may also damage DNA and proteins by HNE and HHE, malondialdehyde (MDA), and acrolein. It has also been reported that LPO within mitochondria is closely connected with apoptosis. Cardiolipin oxidation constitutes a prominent factor responsible for apoptosis initiation via cytochrome $\mathrm{c}$ release and finally activation of proteolytic cascade leading to cell death by apoptosis and subsequently PD pathogenesis [11].

Initially, the disruptions in protein clearance within the ER lumen trigger activation of a pro-adaptive branch of the UPR signaling pathway, the main aim of which is to restore cellular proteostasis. Although $\alpha$-syn has not been identified as a resident protein of the ER, a plethora of studies have proven that it directly interacts with both ER and vesicular traffic components and thus induces ER stress conditions [85]. It has been reported that $\alpha$-syn impairs vesicular trafficking from the ER to the Golgi apparatus via direct interaction with the ras-associated binding 1 (RAB1) GTPase [90,91] or activating transcription factor 6 (ATF6), one of the main UPR signaling branches. $\alpha$-Syn inhibits processing of ATF6 via coat protein complex II (COPII)-mediated ER-Golgi transit induced upon ER stress, which in turn impairs ATF6 activation, attenuates its cytoprotective effect, and triggers apoptosis [92]. Moreover, a study by Betzer et al. demonstrated that $\alpha$-syn aggregates may interfere with calcium metabolism in neurons via activation of ER calcium pump SERCA, which as a result sensitizes cells to ROS production and to apoptosis [93]. Another recent study by Paiva et al. reported that A30P $\alpha$-syn upregulates the expression of the collagen type IV alpha 1 chain (COL42A) gene encoding for collagen IV, an important secretory cargo within the Golgi apparatus, resulting in altered ER/Golgi morphology and increased susceptibility to ER stress in DA neurons [94]. Importantly, numerous studies have confirmed the direct interaction between $\alpha$-syn aggregates and GRP78 chaperone, which may directly activate the UPR signaling pathway when it binds to misfolded proteins $[89,95,96]$.

\section{Other Neurodegenerative Diseases}

HD is a pure genetic, late-onset autosomal dominant disease, in contrast to other neurodegenerative disorders, which in most cases are sporadic (up to 90\%) [73]. The prevalence of HD is estimated at $5-8 / 100.000$ and it usually affects people at a mean age of 35 , regardless of gender [87]. The disease remains progressive and incurable as well as finally leads to imminent death approximately 
15 years after the diagnosis [97,98]. Characteristic symptoms of HD include involuntary, jerky movements of the limbs named twitching or chorea, as well as dystonia, bradykinesia, myoclonus, dementia, personality changes, and depression $[73,99]$. The onset of psychiatric and cognitive defects appears earlier than that of motor abnormalities, during early to mid-adult life $[98,100]$. All mentioned symptoms are caused by a premature loss of the gamma-aminobutyric acid (GABA)-ergic medium-sized spiny neurons of the striatum, projecting to SN pars reticulata and pallidum, as well as other brain regions such as the basal ganglia, cortex, thalamus, or hypothalamus, although to a lesser extent $[87,101,102]$. It has been reported that significant atrophy of the caudate and putamen occurs years before manifestation of the symptoms [101]. HD is caused by an expansion of cytosine-adenine-guanine (CAG) repeats in the $5^{\prime}$ coding region of the HTT gene encoding for a polyglutamine (polyQ) stretch near the N-terminal region of $\mathrm{Htt}[100,103,104]$. The number of CAG trinucleotide repeats is highly polymorphic and differs between healthy individuals from 11 to 34 glutamine repeats, but in HD it exceeds the pathological threshold of 35 repeats [87,103]. Interestingly, the increasing number of expanded CAG repeats accelerates the neurodegeneration process and inversely correlates with the age of both disease onset and death [73,104]. Other "polyglutamine disorders" characterized by polyQ repeats that trigger region-specific neurodegeneration include Machado-Joseph disease (MJD), spinocerebellar ataxia (SCA), or spinobulbar muscular atrophy (SBMA) [100]. Mutation in the HTT gene is completely penetrant and the expansion of 40 or more CAG repeats within the $\mathrm{Htt}$ leads to toxic gain-of-function and progressive accumulation of misfolded $\mathrm{mHtt}$ as intracellular oligomers called inclusion bodies (IBs) [87,97]. Although both soluble and aggregated forms of $\mathrm{mHtt}$ induce cytotoxicity, soluble/oligomeric mHtt are regarded as more toxic [104]. It has also been observed, as in the case of $\alpha$-syn, that such Htt inclusions often co-localize with ubiquitin [98]. IBs aggregate within the cytoplasm and the nucleus and eventually contribute to the selective loss of striatal neurons [87] via induction of series of pathological events, which include transcriptional dysfunction, mitochondrial disturbances, vesicular transport impairment, ER stress, perturbation of calcium signaling, protein trafficking and amino acid metabolism, proteasome inhibition, as well as apoptosis [97]. Although mutant $\mathrm{Htt}$ has not been found to directly accumulate inside the ER lumen, it has been confirmed to interact with the ER membrane and thus interfere with ER function indirectly. Several models have been suggested to explain this phenomenon regarding excitotoxicity, oxidative stress, mitochondrial and proteasome dysfunction, transcriptional disturbances, alterations in axonal transport, or in the secretory pathway [98]. Recent reports have implied that Htt may cause an early defect of the endoplasmic-reticulum-associated protein degradation (ERAD), as it impairs the flux of proteins targeted for degradation, and in turn fosters the accumulation of misfolded proteins within the ER. Mechanistically, mHtt fragments entrap ERAD-associated proteins, namely, glycoprotein 78 (Gp78), nuclear protein localization protein 4 (Np14), ubiquitin fusion degradation protein 1 (Ufd1), and protein 97 (p97), and thus inhibit protein trafficking. The IBs have also been found to impair the protein degradation process via inhibition of the ubiquitin-proteasome system (UPS) [105]. Nevertheless, the actual link between HT and ER stress is yet to be elucidated.

Prion diseases are rare, fatal, and transmissible neurodegenerative disorders that may affect both humans and animals [106]. They may be either inheritable or infectious and include inter alia, Creutzfeldt-Jakob disease (CJD), Gerstmann-Sträussler-Scheinker syndrome (GSS), fatal familial insomnia (FFI), and Kuru [107-109]. The clinical manifestation of prion disease varies considerably according to the type of disorder and thus the affected brain region, but it is usually associated with severe neurological, psychiatric, and cognitive abnormalities [108]. Familial forms of CJD, GSS, or FFI are caused by mutations or insertions in the prion protein (PRNP) gene, encoding for cellular prion protein $(\mathrm{PrPc})$ which naturally occurs in the organism $\left(\mathrm{PrP}^{\mathrm{c}}\right)$ [73]. Sporadic forms, on the other hand, may be caused by spontaneous misfolding of $\mathrm{PrP}^{\mathrm{C}}$ or rare somatic mutations in PRNP [108]. $\operatorname{PrP}^{\mathrm{C}}$ is a soluble, 209-amino acid, $\alpha$-helix-rich protein, with the sequence capable of induction of apoptosis (residues 106-126) and highly conserved hydrophobic C-terminal and $\mathrm{N}$-terminal regions, which anchor the protein into the ER lumen [108]. The role of $\mathrm{PrP}^{\mathrm{c}}$ has not been fully elucidated, although it has been 
linked to neuronal growth and survival, cytoprotection against cellular stress, and tumor necrosis factor (TNF)- and BCL2 associated X (BAX)-mediated cell death [74]. Pathologically, the disease is caused by abnormal folding of $\mathrm{PrP}^{\mathrm{C}}$, resulting in the development of abnormal, protease-resistant scrapie isoform $\left(\mathrm{PrP}^{\mathrm{Sc}}\right)[106,110]$. In comparison with its native form, $\operatorname{PrP}^{\mathrm{Sc}}$ is characterized by three-dimensional conformation and higher $\beta$-sheet structure. It is prone to aggregate in the form of diffuse synaptic plaques, together with amyloid, in the brain and lympho-reticular tissues, leading to spongiform encephalopathy, progressing neuronal loss, astrocytosis, and microgliosis [74,107]. Of note is that the interaction of $\mathrm{PrP}^{\mathrm{Sc}}$ with $\mathrm{PrP}^{\mathrm{C}}$ induces abnormal folding of the native form, which in turn becomes infectious, further amplifies the protein misfolding, and propagates from one cell to another [74]. This event has been linked to aging, as a consequence of failure in antioxidant defense mechanisms, decrease in chaperone activity, and impaired protein degradation process [73]. Moreover, it has been proven that $\mathrm{PrP}^{\mathrm{Sc}}$ is able to self-replicate, despite the absence of genetic material [111].

The ability of misfolded proteins, other than prion protein, to constitute a template for the seed creation from the physiologic form of the same kind of protein, propagate between cells, and spread across the anatomical pathways, is commonly termed as a "prion-like property". Interestingly, it has been reported that propagation of other misfolded proteins in non-infectious neurodegenerative diseases may occur by the mechanisms similar to these characteristic for prion pathogenesis. $A \beta$ and tau proteins in AD; $\alpha$-syn in PD; TAR DNA-binding protein 43 (TDP43), tau, or fused in sarcoma (FUS) proteins in frontotemporal dementia (FTD); and TDP43 in motor neuron disease exhibit some properties of the misfolded prion protein. Multiple pieces of in vitro and in vivo evidence have demonstrated that the self-propagation mechanism by seeding and aggregation of similar misfolded proteins constitutes a characteristic hallmark of not only $\operatorname{PrP}^{\mathrm{Sc}}$ but also A $\beta$, tau, $\alpha$-syn, and TDP43 proteins [112]. It has been demonstrated in an in vitro cellular model that intracellular oligomers may constitute the seeding unit. A $\beta$ seeding nucleation may be initiated inside the APP-producing cells upon their exposure to FAD brain extract [113]. Furthermore, it has been reported that seeding potency of $A \beta$ is the greatest at the beginning of the $A \beta$ aggregation, as well as concurring with a transient increase of the $A \beta_{42} / A \beta_{40}$ ratio. Seeding potency decreases with increasing formation of senile plaques in the brain tissue [114]. Thereby, compounds administrated during the early stages of $A D$, which may interfere with $A \beta$ seeding formation and block the disease progression before the senile plaques aggregate and can be detectable, may represent a novel treatment strategy against AD [112]. Moreover, a tau protein may also constitute a seeding unit such as $\mathrm{PrP}^{\mathrm{Sc}}$. The aforementioned molecular event has been confirmed both in in vitro and in vivo models. It has been suggested that aggregation of tau is initiated via phosphorylated tau fractions characterized by high molecular weight, which were found to be present in the cerebrospinal fluid (CSF) of an AD mouse model or AD individuals [115]. It has also been reported that tau, similarly to prions, propagates numerous conformations from different sporadic tauopathies in vitro as well as initiates distinct pathologies in vivo in mouse models demonstrating human diversity of tauopathies Interestingly, the mentioned conformations of tau are transmissible and may be passaged both in in vitro and in vivo models [116-119]. The seeding activity has also been confirmed for $\alpha$-syn. Brain homogenates from patients with multiple system atrophy (MSA) are responsible for neurodegeneration both in cell models and in transgenic mice [120]. Additionally, oligomer creation is closely associated with the early stages of TDP43 misfolding has been confirmed for various frontotemporal lobar degeneration with TDP-43 inclusions (FTLD-TDP) types as well as in individuals with diagnosed hippocampal sclerosis with TDP43 pathology [121-123]. The cell-based seeding assay has demonstrated that extracts derived from brains with sporadic and familial FTLD-TDP were characterized by a higher seeding potency in comparison with control brain extracts [124]. As mentioned previously, numerous experimental data have reported that prion-like mechanisms are currently established for A $\beta$, tau, $\alpha$-syn, and TDP43 proteins, which constitute crucial components in inducing seeding and subsequently evoke neurotoxicity and neurodegeneration. Many experiments in in vivo models have confirmed transmission and propagation as well as seeding potencies of misfolded proteins, other than prions, which are strictly correlated with neurodegeneration [112]. 
Transmission of protopathic seeds, characteristic for prion disease, have been found in in vivo research including $\mathrm{A} \beta$ transmission in transgenic mice, mutant P301S tau transmission in transgenic mice and from human tauopathies into transgenic mice, $\alpha$-synuclein transmission in transgenic mice using synthetic fibrils and human MSA brain extracts, and TDP43 transmission in transgenic mice using human brain-derived FTLD-TDP extracts [124-127]. Transmission between humans has been described in prion diseases, whereas that prion-like mechanisms has been also observed in individuals that received pituitary-derived $\mathrm{GH}$ and had died of prion disease. In these patients, frequent cerebral amyloid angiopathy (CAA) and parenchymal $A \beta$ have been confirmed [128]. A $\beta$ transmission has also been demonstrated in patients who received contaminated dural grafts and in the post-neurosurgical patients $[129,130]$.

$\operatorname{PrPSc}$ accumulation exhibits a deleterious effect in cells via different signaling cascades, particularly in the ER stress-mediated UPR signaling pathway [106]. $\mathrm{PrP}^{\mathrm{Sc}}$ has been shown to accumulate within intracellular compartments such as the ER, disrupt $\mathrm{Ca}^{2+}$ homeostasis, and hence lead to ER stress-induced apoptosis. Several post-mortem studies have confirmed that UPR-related and apoptotic mediators are activated in infected cells [74], although the detection of this marker is difficult due to the long delay of autopsy in order to take infectivity precautions [107]. For instance, Moreno et al. have reported that accumulation of misfolded PrP resulted in increased phosphorylation of PERK and eIF $2 \alpha$ that triggered attenuation of global protein synthesis within the brain tissue, and hence increased rate of synaptic failure and neuronal atrophy [131]. Conversely, several studies have denied the involvement of UPR in the pathogenesis of prion disease, suggesting that signs of UPR activation are less prominent in prion disease than in other types of neurodegenerative disorders such as AD. The presence of phosphorylated forms of PERK or eIF $2 \alpha$ have not been found in post mortem samples of patients suffering from both genetic and infectious variants of CJD [132]. Likewise, neither p-PERK nor p-IRE1 $\alpha$, the second major branch of UPR signaling, have been detected in brains of scrapie-affected or CJD mice [109]. The main downstream target of the IRE1 $\alpha$ branch of UPR, $x$-box binding protein 1 (XBP1), has also been excluded from involvement in prion pathogenesis, as reported by Hetz et al. [133]. On the other hand, aspects such as activation of caspase-12 in affected neurons as well as whether $\mathrm{PrP}^{\mathrm{C}}$ binds to $\mathrm{A} \beta$ or $\alpha$-syn oligomers still remain controversial, given that numerous different studies have demonstrated opposite results. However, there has been growing evidence for a cross-seeding process between misfolded proteins, as $\alpha$-syn has been proven to be capable of inducing a transmissible spongiform encephalopathy with PrP accumulation [84] (Figure 1). 

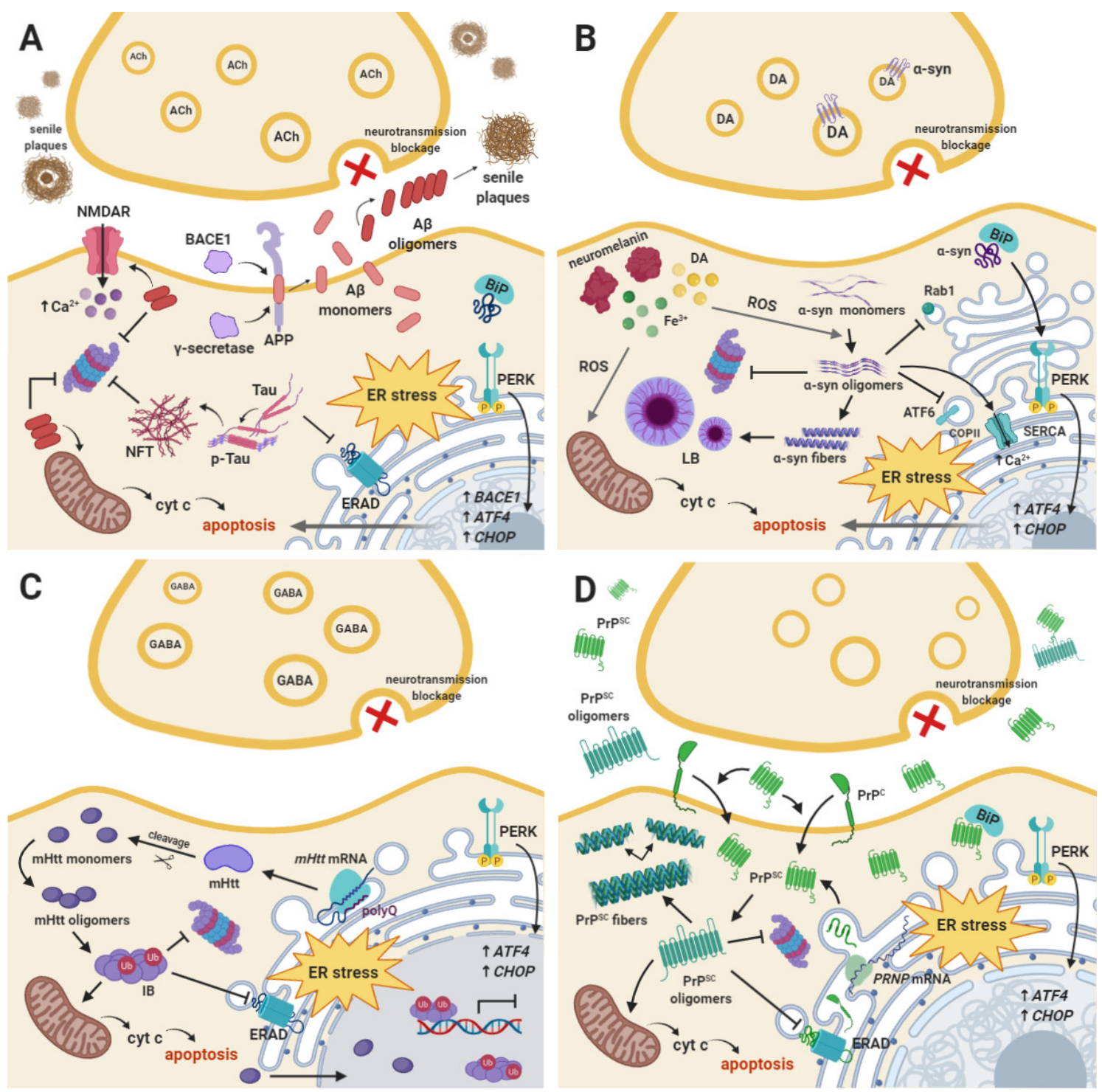

Figure 1. The schematic view of molecular perturbances resulting in subsequent activation of the protein kinase RNA-like endoplasmic reticulum kinase (PERK)-dependent unfolded protein response (UPR) signaling pathway in the following neurodegenerative disorders: (A) Alzheimer's disease (AD), (B) Parkinson's disease (PD), (C) Huntington's disease (HD), and (D) prion disease. More details are included in the text of the manuscript.

\section{ER Stress and the UPR Signaling Branches}

The ER constitutes the main cellular compartment for protein folding and assembly [134]. It is a highly complex organelle not only in its structure, but also in its function, as the ER plays a fundamental role in protein processing, which includes biosynthesis, folding, modification, and their transport. The ER is also an important organelle for biosynthesis and distribution of phospholipids and steroids, detoxification, energy metabolism, nucleus-cytosol signaling, and it is also responsible for the quality control of the newly synthesized proteins. Moreover, it plays a pivotal role in the maintenance of cellular calcium ion homeostasis $[135,136]$. Neuronal $\mathrm{Ca}^{2+}$ homeostasis and signaling are responsible for proper synaptic transmission, plasticity, and cell survival. Disturbances in $\mathrm{Ca}^{2+}$ homeostasis trigger significant dysregulation of neuronal physiology, leading to neuronal dysfunction and degeneration [137]. 
ER homeostasis is essential for cell survival, but a broad range of pathological conditions may disrupt that cellular state and evoke the ER stress conditions. They are directly activated upon glucose deprivation, redox imbalance, calcium homeostasis disruption, and as a response to the accumulation of improperly folded proteins within the ER lumen [29,138]. Aggregation of unfolded and misfolded proteins within the ER and subsequent ER stress conditions trigger activation of the UPR signaling branches, which are responsible for enhanced ER ability for protein folding and attenuation of global protein translation [139]. Interestingly, the UPR is characterized by a dual role, both pro-adaptive and pro-apoptotic. The major role of the UPR is the cellular adaptation for mild and moderate pathological conditions $[140,141]$. However, upon severe or long-termed ER stress conditions, or when the UPR is chemically or genetically impaired and the protein folding disruption is unable to mitigate, the pro-adaptive UPR signaling branches are insufficient to restore ER homeostasis, which consequently activates the pro-apoptotic arm of the UPR [139].

There are three major ER transmembrane proteins that act as sensors of ER stress conditions: PERK, IRE1, and ATF6 [142-144]. The aforementioned transmembrane ER transducers are directly activated by a common stimulus - the accumulation of pathological proteins within the ER lumen. The UPR induction is mediated via upregulation of a wide range of genes that are activated in an IRE1and ATF6-dependent manner, as well as PERK-mediated inhibition of global protein synthesis and transcription of only selective sets of mRNAs [145]. The ER chaperone BiP, also known as $78 \mathrm{kDa}$ glucose regulated protein (GRP78) or heat shock protein family A, member 5 (HSPA5), is commonly known as a major regulator of the ER homeostasis. BiP plays a fundamental role in folding and assembly of newly synthesized proteins and prevents their misfolding and aggregation. As a chaperone, $\mathrm{BiP}$ targets abrogated proteins for proteasome degradation and is responsible for the rapid initiation of the UPR signaling pathways [106]. Under ER homeostasis, BiPs bind to the lumenal domains of the ER transmembrane transducers such as PERK, ATF6, or IRE1 and maintain them in an inactive state. Increased level of misfolded and unfolded proteins within the ER lumen triggers dissociation of BiPs from PERK and IRE1 luminal domains resulting in oligomers formation and activation of the cytosolic effector domains of the sensors by trans-autophosphorylation. Thereby, dissociation of BiPs is necessary to activate PERK and/or IRE1 ER receptors [146]. ATF6, after BiP dissociation, is transported to the Golgi apparatus, where its two-step cleavage by the Golgi site- 1 and site-2 proteases (S1P and S2P, respectively) occurs [147]. The main aim of the above-mentioned event is to generate the cytosolic domain that may be translocated into the nucleus, where it acts as a transcription factor for the UPR-specific genes [148].

Disturbances in all three signaling branches of the UPR are closely connected with the pathogenesis of a broad range of human diseases, but the PERK-mediated signaling pathways directly trigger attenuation of global protein translation that plays a major role in learning and memory processes, synaptic plasticity, and neuronal survival. Thus, there is a strong correlation between the dysregulation of the PERK-dependent branch of the UPR and the development and progression of neurodegenerative diseases [149].

\subsection{PERK-Dependent pro-Adaptive Branch of the UPR}

The plethora of studies have reported that the main aim of the UPR signaling pathways is to protect cells from adverse conditions due to pathological changes in the cellular environment. Moreover, UPR protects the organism by eliminating cells that were exposed to extreme and long-term ER stress conditions. However, the balance between the pro-adaptive and pro-apoptotic response upon activation of the ER stress conditions still remains unclear [150-152].

PERK belongs to the eIF2 $\alpha$ kinase subfamily, which is composed of three additional members - the protein kinase C-related kinase (PKR), the general control nonderepressible 2 (GCN2), and the heme-regulated eIF2 $\alpha$ kinase (HRI). All of them are activated via different stimuli: PKR by double-stranded viral RNA in infected cells, GCN2 by uncharged transfer RNAs (tRNAs) or UV irradiation, and HRI through hemin deprivation in erythroid cells [153]. PERK constitutes one of 
the three major ER transmembrane stress-responsive proteins. It is composed of two major parts, namely, C-terminal cytoplasmic domain with serine/threonine kinase activity and N-terminal ER lumenal domain, as well as the additional short hinge loop that links them. The N-lobe comprises three $\alpha$-helices and five $\beta$-strands, whereas the C-lobe is composed of seven $\alpha$-helices, two short $\beta$-strands, and a long activation loop $[153,154]$.

Under homeostatic conditions in unstressed cells, PERK is presented as a homodimeric, transmembrane ER protein and remains inactive due to BiPs bound to its cytoplasmic domains. However, upon disturbances in the protein folding, resulting in activation of the ER stress conditions, BiPs dissociate from the cytoplasmic domains of PERK [155]. The aforementioned event triggers the transient conversion of PERK's structure from a dimeric to a tetrameric state. After PERK tetramerization, activation loop of the first dimer may reach the catalytic site of the second dimer that directly leads to trans-autophosphorylation of the C-terminal PERK domain and subsequent phosphorylation of PERK substrates [154,156].

PERK activation promotes phosphorylation of the subunit $\alpha$ on Ser51 of the eIF2 $\alpha$, which acts as a major substrate of PERK [157-159]. This results in the attenuation of the global protein synthesis and, on the contrary, enhanced translation of only selective sets of mRNAs, including ATF4 [160]. Upon mild-to-moderate ER stress conditions, ATF4 constitutes a transcription factor for genes encoding proteins essential for restoration of cellular homeostasis, including ER chaperones, proteins required for proper amino acid metabolism, redox balance, autophagy, as well as cholesterol metabolism [135,161,162]. Thus, upon activation of the pro-adaptive UPR signaling pathway, transcription of genes encoding proteins such as $\mathrm{BiP}$, calreticulin, calnexin, and protein disulfide isomerases (PDI) is significantly upregulated [163].

Another protein upregulated in a PERK-dependent manner is BACE1, which is directly involved in AD pathogenesis [160]. There is a body of evidence that an increased level of p-eIF2 $\alpha$ is closely associated with higher expression of BACE1, which implies the involvement of the PERK-dependent UPR signaling pathway in BACE1 overexpression and promotion of amyloidogenesis. Numerous studies addressing this issue have been performed in vivo in a mouse model of AD with similar results $[47,164-166]$. However, to evaluate the role of eIF2 $\alpha$ phosphorylation in A $\beta$-dependent BACE1 elevation in primary neuron culture and in the brain of the 5XFAD mouse model of aggressive amyloid pathology, Sadleir et al. used three genetic strategies: DNA damage-inducible 34 (GADD34) cytosine-adenine adeno-associated virus (CA-AAV) transduction, eIF2 $\alpha$ S51A knock-in mutation, and BACE1-yellow fluorescent protein (YFP) transgene lacking upstream open reading frames (uORFs) in the 59 untranslated region (59UTR uORFs). Both in vitro and in vivo experimental models demonstrated that partial or complete reduction of eIF2 $\alpha$ phosphorylation cannot inhibit the A $\beta$-mediated increased level of BACE1. Moreover, it has been shown that YFP-tagged BACE1, expressed from a transgene with a truncated BACE1 mRNA 59 UTR lacking uORFs required for p-eIF2 $\alpha$-mediated translational control, was increased and may aggregate around plaques in a pattern identical to endogenous BACE1 in an 5XFAD brain. Moreover, reduced level of p-eIF2 $\alpha$ did not block A $\beta$-dependent APP elevation in primary neurons and also did not decrease $A \beta$ levels or senile plaque pathology in 5 XFAD brain. Thereby, aforementioned outcomes have demonstrated that, both in primary neurons and 5XFAD mice, eIF2 $\alpha$ phosphorylation does not play a crucial role in A $\beta$-mediated BACE1 and APP elevation, as well as in amyloid pathology [167]. Hence, the above-mentioned findings suggest that the PERK-dependent elevation of BACE1 might be taken into consideration and further elucidated.

There is ample evidence that activation of UPR signaling is present in the models of multiple neurodegenerative disorders. Markers of the UPR induction were found not only in brain tissues of animal models of neurodegeneration, but also in post mortem samplings of human brains with neurodegenerative disorders $[149,168]$. Thereby, activation of the UPR may be either somehow correlated with the pathogenesis of the diseases or could result from a completely different primary cause of neurodegeneration. As a protective signaling activated in response to different stressors, it may ultimately be unable to rescue remining neurons that are overwhelmed with prolonged stress 
conditions. Such a thesis should, however, be taken into consideration cautiously in light of the fact that numerous studies have declined the involvement of UPR in neurodegenerative processes.

\subsection{PERK-Dependent pro-Apoptotic Branch of the UPR}

Interestingly, failure of the pro-adaptive arm of the UPR occurs when the restoration of the cellular homeostasis is impossible. This event directly evokes activation of the pro-apoptotic branch of the UPR signaling pathway, but the underlying mechanisms responsible for the aforementioned molecular switch has not been completely elucidated [169]. There is ample evidence that, despite the pro-adaptive role of ATF4, it also has a negative impact on synaptic plasticity and memory consolidation [170-173]. ATF4, upon excessive or prolonged ER stress conditions, markedly upregulates expression of the DNA damage-inducible transcript 3 (DDIT3) gene that encodes $\mathrm{CHOP}$, which represents the major pro-apoptotic factor of the UPR signaling pathways $[174,175]$. Under physiological conditions, cells are characterized by extremely low expression of $\mathrm{CHOP}$. However, when the self-protect mechanisms within the cells are insufficient to overcome the ER stress, cells undergo CHOP-mediated apoptosis [50,176]. It has been reported that $\mathrm{CHOP}$, as a transcription factor, may regulate expression of both pro- and anti- apoptotic genes, the products of which belong to the B cell lymphoma-2 (Bcl-2) family of proteins. Furthermore, CHOP may also upregulate expression of DNA damage-inducible 34 (GADD34), Tribbles-related protein 3 (TRB3), and endoplasmic reticulum oxidoreductin 1 (ERO1 $\alpha$ ) [177].

Zinszer et al. have reported that, upon ER stress conditions in CHOP knock-out (KO) mouse embryonic fibroblasts (MEFs), cellular apoptosis was found to be significantly less frequent than in wild type MEF cells. Moreover, upon activation of ER stress in $\mathrm{CHOP}^{+/+}$and $\mathrm{CHOP}^{+/-}$mice, early expression of $\mathrm{CHOP}$ occurred, whereas in a $\mathrm{CHOP}^{--}$animal model the evidence of cellular death was significantly reduced [178]. CHOP markedly enhances upregulation of genes encoding pro-apoptotic Bcl-2 homology 3 (BH3)-only proteins such as the p53 upregulated modulator of apoptosis (PUMA), Phorbol-12-myristate-13-acetate-induced protein 1 (NOXA), and Bcl-2-like protein 11 (BIM) [179]. These aforementioned pro-apoptotic $\mathrm{BH} 3$-only proteins play a key role in the mitochondrial-dependent cell death by apoptosis. PUMA, NOXA, and BIM promote activation of BAX and BCL2-antagonist/killer 1 (BAK), which subsequently oligomerize in the outer mitochondrial membrane (OMM) and create pores, resulting in the release of cytochrome $\mathrm{c}$ into the cell cytoplasm. This leads to formation of apoptosome and subsequent caspase activation, which directly evokes apoptosis [180]. Moreover, CHOP may also directly downregulate expression of anti-apoptotic Bcl-2 proteins [179,181,182]. ER stressors caused marked increase in PUMA and BIM level within mouse cortical neurons [183]. Due to deficiency in BIM and PUMA, apoptosis was significantly decreased in neuronal precursor cells in mouse hippocampus [184]. Moreover, under ER stress conditions, neuronal SH-SY5Y KO cells were characterized by decreased level of pro-apoptotic PUMA and BIM proteins [185]. Thus, consistent with the aforementioned data, the level of pro-apoptotic proteins such as BIM is markedly upregulated, as well as the level of anti-apoptotic proteins such as Bcl-2 being significantly decreased under ER stress conditions evoked by oligomeric A $\beta$ treatment, which directly induces neuronal cell death [186].

Another target of CHOP constitutes TRB3, which due to pathogenesis of human diseases is characterized by a dual role. It has been reported that TRB3 plays an important role in a negative feedback loop under mild to moderate ER stress conditions, which may block its pro-apoptotic activity. Thus, the aforementioned TRB3-mediated molecular mechanism may result in restoration of cellular homeostasis. On the contrary, under adverse ER stress pathological conditions, TRB3 plays a critical role in Akt inhibition, resulting in apoptotic cell death [182].

Additionally, CHOP also enhances expression of growth arrest and DNA damage-inducible 34 (GADD34), which creates a complex with the catalytic subunit of protein phosphate 1 (PP1) that directly triggers dephosphorylation of eIF2 $\alpha$ during later stages of the ER stress response [187]. Interestingly, p-eIF2 $\alpha$ dephosphorylation plays a neuroprotective role, as it directly restores global protein translation [131]. It has been reported that expression of GADD34 is ER stress-dependent, as it was absent in PERK KO cells [188]. There is abundant evidence that increased level of GADD34 
may significantly enhance apoptosis $[189,190]$. Mechanistically, p-eIF2 $\alpha$-mediated activation of ATF4/CHOP/GADD34 arm of the UPR signaling pathway inhibits the phosphorylation of eIF2 $\alpha$ in a negative feedback loop and thus promotes translational recovery. This rapidly increases the level of ER nascent proteins entering the ER, enhances ER stress, and subsequently leads to cell death via apoptosis $[191,192]$. These findings are supported by the fact that salubrinal, a selective small-molecule inhibitor of eIF2 $\alpha$ dephosphorylation, has been reported to prevent apoptotic cell death under prolonged ER stress conditions in the derived from a rat pheochromocytoma (PC12) cell line [193].

CHOP constitutes a transcription factor for the ERO1 $\alpha$ gene, which plays a key role in the formation of disulfide bonds when cells remain under a homeostatic state. However, under severe, long-termed ER stress conditions, ERO1 $\alpha$ evokes significantly elevated generation of $\mathrm{H}_{2} \mathrm{O}_{2}$, promoting a hyperoxidizing environment, and thus apoptotic cell death [194]. There is strong evidence that cerebral ischemia may constitute a significant risk factor for neurodegeneration [195-197]. It has been reported that cerebral ischemia evokes the ER stress conditions that activate the UPR signaling pathways [198]. In an animal model, global ischemia led to increased expression of $\mathrm{CHOP}$ and its downstream targets ERO1 $\alpha$ in the hippocampal neurons [199]. CHOP-mediated upregulation of ERO1 $\alpha$ causes activation of calcium-release channel inositol-1,4,5-trisphosphate receptor 1 (IP3R1), resulting in leakage of $\mathrm{Ca}^{2+}$ into the cell cytoplasm. Increased level of $\mathrm{Ca}^{2+}$ activates calcium/calmodulin-dependent protein kinase II (CaMKII), which in turn induces multiple apoptotic signaling pathways [200], including activation of nicotinamide adenine dinucleotide phosphate-oxidase (NADPH) subunit 2 (NOX2) and subsequently increases concentration of reactive oxygen species (ROS). This molecular event results in a positive feedback loop, as ROS generated via NADPH oxidase promote enhanced expression of CHOP, leading to apoptotic cell death $[201,202]$ (Table 1). 
Table 1. The correlation between the expression of PERK-dependent unfolded protein response (UPR)-related proteins and proteostasis disturbances in various neurodegenerative disorders. The upregulation of specific UPR markers in the listed experimental models is indicated as an up-arrow $(\uparrow)$, whereas downregulation as a down-arrow $(\downarrow)$.

\begin{tabular}{|c|c|c|}
\hline Neurodegenerative Disease & UPR Markers & Experimental Model \\
\hline \multirow[t]{7}{*}{ Alzheimer's disease } & $\uparrow$ GRP78 & $\begin{array}{l}\text { A } \beta \text {-treated SK-N-SH cells [203], RBE4 cells [204], A } \beta_{1-40} \text {-treated RBE4 cells [205], A } \beta_{1-42} \text {-treated bEnd.3 cells [206], 5XFAD mouse model [207], } \\
\text { APP/PS1 transgenic mice [208], A } \beta_{1-42} \text {-treated rat astrocytes, 3xTg-AD mice [209], mutant PS1 cells, 3xTg-AD mice [210]. }\end{array}$ \\
\hline & $\downarrow$ GRP78 & PS1 mutant SK-N-SH cells [211]. \\
\hline & $\uparrow$ PERK & $\begin{array}{l}\text { Hippocampus of human AD brains [48], 5XFAD mouse model [160,166], A } \beta \text {-treated SK-N-SH cells [203], JNPL3 mice, rat cortical neurons [212], } \\
\qquad \mathrm{A} \beta_{42} \text { transgenic flies [213], pR5 mice [214]. }\end{array}$ \\
\hline & $\uparrow \mathrm{p}-\mathrm{eIF} 2 \alpha$ & $\begin{array}{l}\text { AD mouse model [215], hippocampus of human AD brains [48], 5XFAD mouse model [160,166], APP/PS1 mice [216], A } \beta \text {-treated SK-N-SH cells [203], } \\
\text { JNPL3 mice, primary cultures of rat cortical neurons [212], A } \beta_{1-42} \text {-treated rat embryonic hippocampal neurons [217], pR5 mice [214], A } \beta_{1-42} \text {-treated } \\
\text { rat primary cortical neurons [218], A } \beta_{1-42} \text {-treated rat cerebral cortical astrocytes [209]. }\end{array}$ \\
\hline & $\uparrow$ ATF4 & $\begin{array}{l}\text { 5XFAD mouse model [160,166], } \mathrm{A} \beta_{1-40} \text {-treated RBE4 cells [205], human APOEe4 allele-expressing human and mouse AD models [219], } \\
\mathrm{A} \beta_{1-42} \text {-treated rat embryonic hippocampal neurons, } \mathrm{A} \beta_{1-42} \text {-treated mice, human AD brains [217], Arg-61 APOE astrocytes [220]. }\end{array}$ \\
\hline & $\uparrow \mathrm{CHOP}$ & $\begin{array}{l}\text { A } \beta \text {-treated SK-N-SH cells [203], primary rat cortical neurons [212], RBE4 cells [204], temporal cortex of human AD brains [221], A } \beta_{1-40} \text {-treated RBE4 } \\
\text { cell line [205], A } \beta_{1-42} \text {-treated bEnd.3 cells [206], 5XFAD mouse model [207], APP/PS1 transgenic mice [208]. }\end{array}$ \\
\hline & $\uparrow$ GADD34 & J20 mice [222], AD mouse model, human AD brains [223]. \\
\hline \multirow[t]{8}{*}{ Parkinson's disease } & $\uparrow$ GRP78 & $\begin{array}{l}\text { SYN120 mice, SH-SY5Y+ cells, HEK } 293 \text { cells [95], PARK14 knock-in mouse model [224], 6-OHDA-treated MN9D cells [225], 6-OHDA-treated } \\
\text { SH-SY5Y cells [226]. }\end{array}$ \\
\hline & $\downarrow$ GRP78 & Rat PD model [227,228], human PD brains [229], DJ-1 KO neurons, MEFs and KD SH-SY5Y+ cells [230]. \\
\hline & $\uparrow$ PERK & $\begin{array}{l}\text { Human PD brains, rat PD models [231], PARK20 fibroblasts [232], mouse model of chronic MPTP/P injection [233], rat PD model [228], PARK14 mice } \\
\text { [224], 6-OHDA- or MPP+ }{ }^{+} \text {-treated MN9D cells [225], Drosophila PINK1 and PARKIN mutants [234], DJ-1 KO MEFs [230]. }\end{array}$ \\
\hline & $\uparrow \operatorname{eIF} 2 \alpha$ & PARK20 fibroblasts [232], mouse model of chronic MPTP/P injection [233], 6-OHDA- or MPP+-treated MN9D cells [225], DJ-1 KO MEFs [230]. \\
\hline & $\uparrow$ ATF4 & Rat PD model [235], PD cellular models [95], mouse model of chronic MPTP/P injection [233], PARK20 fibroblasts [232]. \\
\hline & $\downarrow$ ATF4 & $\begin{array}{l}\text { DJ-1 KO neurons, MEFs and KD SH-SY5Y+ cells [230]. } \\
\text { 6-OHDA- or MPP+ - treated MN9D cells [225] 6-OHDA-treated SH-SY5Y cells [226]. PARK14 mice [224] rat PD model [228] PARK20 fibroblasts }\end{array}$ \\
\hline & $\uparrow \mathrm{CHOP}$ & $\begin{array}{l}\text { 6-UHDA- or MIPP - treated MINYD cells [225], 6-UHDA-treated SH-SY5Y cells [226], PARK14 mice [224], rat PD model [2Z8], PARK20 fibroblasts } \\
\text { [232]. }\end{array}$ \\
\hline & $\downarrow \mathrm{CHOP}$ & DJ-1 KO neurons, MEFs and KD SH-SY5Y+ cells [230]. \\
\hline \multirow[t]{7}{*}{ Huntington's disease } & $\uparrow$ GRP78 & PC6.3 cell [236], mHtt-expressing 293 Tet-Off cells [237], PC12-Q79 cells [238], HEK293T cells [239], Htt150Q-expressing N2a cells [240]. \\
\hline & $\downarrow$ GRP78 & mHtt-expressing mouse striatal cell lines [241]. \\
\hline & $\uparrow$ PERK & Human and murine striatal cells, N171-82Q mice [242], PC12-Q79 cells [238]. \\
\hline & $\uparrow \mathrm{eIF} 2 \alpha$ & Human and murine striatal cells, N171-82Q mice [242], 120Q-Htt-expressing PC6.3 cells [243]. \\
\hline & $\uparrow$ ATF4 & Q7 cells [244]. \\
\hline & $\downarrow$ ATF4 & Q111 cells [244]. \\
\hline & $\uparrow \mathrm{CHOP}$ & PC6.3 cell [236], PC12-Q79 cells [238], Q7 and Q111 cells [245], HEK293T cells [239]. \\
\hline \multirow[t]{6}{*}{ Prion disease } & $\uparrow$ GRP78 & $\begin{array}{l}\text { PrP-expressing N2a cells [246], PrP(106-126)-treated NT2 rho0 cells and NT2 rho0+ cells [247], PrP-expressing N2a cells [248], 263K infected hamsters } \\
\text { brain tissues, PrP-expressing 293-T cells [249], brains of BSE cattle [250], PrP-treated M17 cells [251]. }\end{array}$ \\
\hline & $\downarrow$ GRP78 & Prion infected GRP78 ${ }^{+/-}$and GRP78 ${ }^{+/+}$mice, CAD5 cell line [106], CaBP-KO mice [252], PrP-treated CR7 cells [253]. \\
\hline & $\uparrow$ PERK & Prion-infected mice [254], POM1-treated cultured organotypic cerebellar slices [255], FTgpi mice [256]. \\
\hline & $\uparrow \mathrm{p}-\mathrm{eIF} 2 \alpha$ & Prion-diseased mice [131,254], POM1-treated cultured organotypic cerebellar slices [255], FTgpi mice [256]. \\
\hline & $\uparrow$ ATF4 & POM1-treated cultured organotypic cerebellar slices [255]. \\
\hline & $\uparrow \mathrm{CHOP}$ & FTgpi mice [256], PrP-expressing N2a cells [246], CaBP-KO mice [252], PrP-treated SH-SY5Y cells [257]. \\
\hline
\end{tabular}




\section{Modulatory Compounds of the UPR Signaling Pathways}

Recent data have reported that perturbations in the UPR signaling branches might play a role in the development and progression of multiple human diseases, including neurodegenerative disorders. It has been demonstrated that overactivation of PERK-eIF $2 \alpha$ phosphorylation occurs in several transgenic mouse models of $\beta$-amyloidosis and tauopathy. There is also evidence that the PERK-eIF2 $\alpha$ signaling pathway may potentially be involved in the progression of $\mathrm{AD}$ and other neurodegenerative diseases, the main hallmarks of which are memory deficits [54]. These data led to the prediction that pharmacological modulation of the PERK-dependent UPR signaling pathways may result in a significant neuroprotective effect. Thereby, targeting of the ER stress-dependent UPR signaling branches may contribute to the development of a novel, ground-braking treatment strategy against neurodegeneration $[107,149,258]$.

\subsection{GSK2606414}

GlaxoSmithKline(GSK)2606414 is the first-generation PERK inhibitor that is characterized by $30 \mathrm{nM} \mathrm{IC} \mathrm{I}_{50}$ as well as good cellular in vitro and in vivo potency. It has been regarded as highly-selective for PERK, as its selectivity is $>385$-fold for PERK over other eIF2 $\alpha$ kinases [259]. The transient repression of protein synthesis in a mouse model of prion disease induced in the PERK-dependent manner was challenged after treatment with small-molecule PERK inhibitor GSK2606414. Moreover, GSK2606414-treated prion-infected mice demonstrated a significantly decreased level of the phosphorylated form of PERK and eIF $2 \alpha$ in comparison with vehicle-treated mice. Additionally, in an animal model of PrP disease, after GSK2606414 treatment, the levels of ATF4 and CHOP were markedly reduced, which confirmed the neuroprotective effect of GSK2606414 [254]. Radford et al. showed that PERK-eIF2 $\alpha$-dependent repression of global protein synthesis also acts as a key mediator in neuronal loss in mouse model of FTD, in which ER stress is directly evoked by mutant protein tau. Brain tissue of $\mathrm{rTg} 4510$ mice that overexpressed the P301L tau mutation was characterized by high level of p-PERK and p-eIF $2 \alpha$ and transient translational repression by mice aged 6 months. The level of p-PERK, p-eIF2 $\alpha$, and ATF4 was significantly reduced in P301L transgene-expressing mice orally treated with GSK2606414. Furthermore, global protein synthesis was restored in GSK2606414-treated tauP301L+ mice in comparison with vehicle-treated mice. Treatment with GSK2606414 also evoked reduction of the level of phospho-tau protein, which provides the additional mechanism of protection against neurodegeneration. The histological features of the neuroprotective effect of GSK2606414 included rescue in number of cornu ammonis 1 CA1 neurons to approximately $60 \%$, as compared to vehicle-treated mice that demonstrated profound hippocampal neuronal loss characteristic for FTD, with about $25 \%$ neurons preserved. Moreover, a significant reduction in brain atrophy as well as greater total brain weights were observed in PERK inhibitor-treated animals in comparison with untreated transgene-expressing animals at the same stage of the disease. Moreover, mentioned features after treatment with GSK2606414 were comparable to these observed in mice at early stages of the disease. Of note were that the treatment of mice started at 6 months old, when the progressive changes in the hippocampus had already begun, which supports the fact that GSK2606414 deterred already progressing neurodegeneration [260].

It has been reported that use of PERK inhibitor GSK2606414 may also constitute a promising treatment strategy against the neurodegeneration in PD. Interestingly, pharmacological induction of ER stress conditions by tunicamycin and oral administration of GSK2606414 triggered significant inhibition of the PERK-mediated UPR signaling pathways in the SNpc of mice injected with neurotoxin 6-hydroxydopamine (6-OHDA). Moreover, GSK2606414 treatment evoked an increased level of dopamine as well as expression of synaptic proteins [231].

It is worth mentioning that not only does GSK2606414 prevent neuronal loss, but it also positively influences cognitive function and alleviates the clinical symptoms of neurodegeneration. For instance, in the mentioned experiment by Radford et al., GSK2606414-treated mice at 8 months of age exhibited normal grooming, posture, and movement, whereas vehicle-treated animals demonstrated poor 
grooming, hunched posture, and impaired mobility at the same stage [260]. In another study by Ounallah-Saad et al., it has been proven that GSK2606414 is responsible for cognitive enhancement via reduction of p-eIF2 $\alpha$ levels. After injection of the inhibitor into the rat insular cortex, the incidental taste learning and conditioned taste aversion (CTA) procedures were performed. PERK inhibitor enhanced novel taste learning, associative memory (higher aversion), as well as extinction of CTA compared to the vehicle-injected group, which suggests increase in cortical-dependent behavioral plasticity. Interestingly, genetic silencing of PERK in tested animals has also been performed with similar results [261]. A recent study by Zhu et al. has also found that inhibition of PERK with GSK2606414 affects working memory, as mice treated with the inhibitor appeared to be impaired in a spontaneous alternation Y-maze task as well as in fear extinction, which implies the impairment of spatial working memory and memory flexibility, respectively [262]. Lastly, Sharma et al. reported that reduction of PERK expression by GSK2606414 improved hippocampal-dependent memory and learning, as well as increasing neuronal excitability after injection into the CA1 region in middle-aged mice. Notably, the hippocampal memory in mice was restored to the normal performance levels observed in young individuals [263].

Interestingly, Grande et al. have demonstrated in an in vivo experimental model that inhibition of the PERK-mediated UPR response signaling branches via GSK2606414 delayed neurodegeneration, prolonged the asymptomatic phase of the disease, and markedly improved motor function in a mouse model of Marinesco-Sjögren syndrome [264].

Although there is a significant neuroprotective effect of GSK2606414 in multiple neurodegenerative disorders, it has also been reported that treatment with GSK2606414 evokes a cytotoxic effect, resulting in body weight loss and, due to increased blood glucose level, hyperglycemia in a mouse model of prion disease [254]. Moreover, treatment with GSK2606414 of prion-infected mice evoked side effects that may be correlated with pancreatic toxicity [231].

\subsection{GSK2656157}

Due to the above-mentioned side effects triggered by GSK2606414, the second generation of PERK inhibitors, which embrace GSK2656157, has been discovered. GSK2656157 is non-toxic due to better pharmacokinetics and physical properties in comparison with GSK2606414 [265]. Importantly, GSK2656157 has an IC $_{50}$ of $0.9 \mathrm{nM}$ and it is characterized by high selectivity for PERK. It has been reported that GSK2656157 may inhibit PERK activity in cells with an $\mathrm{IC}_{50}$ in the range of 10-30nM. Atkins et al. showed significant inhibition of PERK and eIF2 $\alpha$ phosphorylation that was correlated with decrease in ATF4 and CHOP protein levels in a broad range of cell lines with evoked ER stress conditions [266].

Nevertheless, the latest study by Rojas-Rivera et al. has provided a solid evidence that both mentioned GSK inhibitors appear to be in fact inhibitors of the receptor-interacting serine/threonine-protein kinase 1 (RIPK1), rather than of PERK. It has been proven that both compounds effectively inhibit tumor necrosis factor (TNF)-mediated RIPK1-dependent cell death via apoptosis or necroptosis. It is of note that this effect was independent of PERK inhibition. Both GSKs inhibited TNF-mediated RIPK1-mediated cell death at a concentration that cannot affect PERK activity within cells. Surprisingly, the inhibitory activity of GSK2656157 against RIPK1 was comparable to the activity of GSK'963, about 800-fold higher than that of NEC-1 and 200-fold higher than that of NEC-1s, all of which are widely used, specific RIPK1 inhibitors. Thus, the mentioned finding implies that all experiments performed with GSK2606414 or GSK2656157 are burdened with a high risk of errors and misinterpretation. Thus there is a requirement to use a novel AMG'44 inhibitor for PERK pharmacological inactivation rather than GSKs, as far as AMG'44 is regarded as selective for PERK and not interacting with RIPK1. Additionally, further studies need to be performed in order to determine the full potency of the GSK2656157 compound in terms of efficient inhibition of additional kinases of human kinome, despite RIPK1 and PERK [265]. 


\subsection{Salubrinal}

A study by Moreno et al. showed that PERK-mediated eIF2 $\alpha$ phosphorylation and subsequent transient repression of global protein synthesis led to chronic progression of neurodegenerative diseases. Treatment of prion-infected mice with salubrinal, as a small-molecule inhibitor of the eIF $2 \alpha$ phosphatase enzymes, demonstrated the opposite effect to previously tested PERK inhibitors [13]. Salubrinal selectively inhibited eIF2 $\alpha$ dephosphorylation, evoked an increased level of p-eIF $2 \alpha$, and accelerated neurotoxicity. Moreover, it markedly reduced survival in prion-infected mice as compared to prion-infected mice untreated with salubrinal. Thus, this investigation established that the inhibition of the PERK-dependent UPR signaling pathways may constitute a novel therapeutic strategy against neurodegenerative diseases [131]. Furthermore, $\mathrm{O}^{\prime}$ Connor et al. have demonstrated that salubrinal significantly elevated $\beta$-secretase expression and subsequently $A \beta$ generation in primary cortical neurons. Thereby, obtained results have suggested that salubrinal may promote amyloidogenesis and increased levels of p-eIF2 $\alpha$, which plays a key role in the molecular mechanism directly leading to AD development and progression [47]. Conversely, Huang et al. have shown that only long-term treatment (46h) with salubrinal evoked an increased level of the p-PERK-mediated AD markers. Interestingly, short-time treatment (6h) with salubrinal had no effect on eIF2 $\alpha$ phosphorylation, but it evoked inhibition of the nuclear factor-kappa B (NF-kB) signaling pathway that protected against $A \beta$-mediated neuronal apoptosis and activation of microglial in rat primary cortical neurons and mouse microglial BV-2 cells [267]. Additionally, a study by Lee et al. has demonstrated that salubrinal, as an activator of UPR signaling branches, triggered significantly raised level of BiPs, resulting in attenuation of A $\beta$-induced neuronal apoptosis [203]. Consistently with the above-mentioned investigations that have confirmed a neuroprotective effect of Salubrinal, research by Reijonen et al. has established reduced ER stress conditions evoked by deposition of $\mathrm{mHtt}$ within the ER lumen of salubrinal-treated, neuronal PC6.3 cells. The neuroprotective effect of salubrinal was evoked by increased levels of p-eIF2 $\alpha$ and BiPs, as well as reduced cleavage of caspase-12 [236].

Additionally, treatment with salubrinal appeared to be effective in several models of PD. It has been reported that salubrinal significantly attenuated the disease symptoms in animals with $\alpha$-synucleinopathy. For instance, in the A53T mutant human $\alpha \mathrm{S}$ transgenic (A53T $\alpha S$ ) transgenic (Tg) mice, salubrinal extended the life span, reduced ER accumulation of $\alpha$-syn, and delayed the onset of motor dysfunction; however, it failed to attenuate the disease progression. Interestingly, it has been suggested that the mechanism of action of salubrinal in the mentioned model resulted from activation of CHOP, the eIF2 $\alpha$ downstream reporter, rather than from increase in p-eIF2 $\alpha$ levels. Remarkably, salubrinal significantly decreased microsomal accumulation of monomeric and oligomeric forms of $\alpha$-syn [268], consistently with the result from another report in which treatment with salubrinal attenuated the accumulation of toxic $\alpha$-syn oligomers [269]. Conversely, in an A53T $\alpha S$ AAV-rat model, salubrinal treatment did not prevent dopaminergic neurodegeneration, but it attenuated the Golgi fragmentation in remaining DA neurons, thus preventing further neuronal loss and alleviated the symptoms [268]. According to another reports, the dose of $5 \mathrm{mM}$ of salubrinal partially prevented $A 53 T \alpha S$-induced cytotoxicity in the PC12 cell line, and this effect was not enhanced by further increase in dosage of the compound. However, after the addition of $50 \mathrm{mM} \mathrm{z}$-VAD, a pan-caspase inhibitor, the cell death was almost completely evaded [270]. Numerous studies have identified that salubrinal protected SH-SY5Y cells either from rotenone- or paraquat-induced neurotoxicity via interfering with death/survival-related signaling pathways such as ATF4 or apoptosis signal-regulating kinase 1 (ASK1), respectively [271-273]. Salubrinal also appeared to be effective in a mouse model of kainic acid (KA)-induced hippocampal degeneration, wherein it prevented cell death in the cornu ammonis 3 (CA3) region of the hippocampus [274].

\subsection{ISRIB}

Sidrauski et al., through the cell-based screen for small-molecule inhibitors of PERK-dependent signaling pathway, have identified the ISRIB compound with $5 \mathrm{nM}$ of $\mathrm{IC}_{50}$ and good BBB penetration. 
There was no effect on PERK and eIF2 $\alpha$ phosphorylation after treatment of ER-stressed human bone osteosarcoma epithelial cells (U2OS) with the ISRIB inhibitory compound. Unexpectedly, ISRIB inhibited expression of downstream targets of the PERK-dependent UPR signaling pathways such as ATF4, CHOP, and GADD34. Furthermore, there was no inhibitory effect of ISRIB on global protein translation. Moreover, upon activation of GCN2 and HRI kinases, ATF4 expression was inhibited after ISRIB treatment. Hence, these data indicate that ISRIB acts as an inhibitor of downstream targets of all eIF $2 \alpha$ kinases. In vivo investigation has demonstrated no cytotoxic effect of ISRIB, as well as selectively enhanced long-term memory in eIF2 $\alpha+/ S 51$ A ISRIB-treated mice [275]. Importantly, ISRIB exhibited high selectivity to ER-stressed cells. Treatment with ISRIB attenuated expression of p-eIF2 $\alpha$-dependent targets including ATF4, CHOP, and GADD34. However, there was no significant translational changes, with the exception of a decreased level of translation of a few mRNAs including ATF4, in non-stressed cells [276]. Halliday et al. demonstrated that both GSK2606414 and ISRIB are characterized by a neuroprotective effect. After treatment with ISRIB of prion-infected mice, decreased loss of hippocampal neurons and reduced prion spongiform pathology were observed. However, in comparison with ISRIB, chronic treatment with GSK2606414, due to its high toxicity, resulted in approximately $50 \%$ reduction in pancreatic weight and destruction of pancreatic tissue in prion-infected mice. ISRIB only partially restores global protein translation, as compared with GSK2606414, which evokes complete recovery of global protein synthesis in pancreatic cells [277]. In PC12 neuronal cells treated with ISRIB, the $A \beta_{1-42}$-induced apoptotic cell death was significantly decreased in comparison with PC12 cells treated solely with $\mathrm{A} \beta_{1-42}$ peptide. Moreover, ISRIB evoked inhibition of $\mathrm{A} \beta_{25-35}$-mediated ATF4 expression in the PC12 cell line. However, ISRIB has no impact on $A \beta$ generation, as $A \beta$ production was not inhibited in ISRIB-treated HEK293T cells [278]. Although there is a significant neuroprotective effect of ISRIB without a cytotoxic effect, ISRIB cannot constitute novel UPR inhibitor against human neurodegenerative diseases due to its high insolubility [149,279].

\subsection{Guanabenz}

Guanabenz (GBZ) is a small-molecule inhibitor that enhances PERK-mediated UPR signaling pathways through selective inhibition of GADD34-dependent dephosphorylation of p-eIF2 $\alpha$. GBZ interferes with GADD34, which consequently prevents GADD34-PP1C complex assembly, resulting in an increased level of p-eIF $2 \alpha$ and its downstream targets. GBZ also restores global protein translation, and thereby significantly increases chaperone synthesis. The aforementioned GBZ-mediated events directly evoke a prolonged pro-adaptive response under ER stress conditions in human cells [280]. A study by Wang et al. demonstrated that GBZ markedly inhibited GADD34-dependent eIF2 $\alpha$ dephosphorylation, resulting in significant amelioration of disease onset, prolonged early phase of disease, and survival in a G93A transgenic mouse model of amyotrophic lateral sclerosis (ALS), as compared to G93A mice untreated with GBZ [281]. Contrarily, it has been demonstrated that GBZ is characterized by high affinity for $\alpha 2$-adrenergic receptors and antihypertensive action. However, GBZ elicits other side effects including drowsiness, dry mouth, weakness, and tiredness in patients, and thereby it cannot be used as a selective inhibitor of GADD34-PP1C assembly [282,283].

\subsection{Sepin1}

There is a plethora of studies that indicate that targeting phosphatases via small-molecule inhibitors may contribute to significant amelioration of neurodegenerative disease symptoms. Hence, Sephin1 has been extensively studied as the second selective inhibitor of holophosphatase. Sephin1, like GBZ, possesses the ability to create a complex with a regulatory subunit of PP1, namely, GADD34. This event results in prolonged eIF $2 \alpha$ phosphorylation, under ER stress conditions, and inhibition of global protein translation recovery. Das et al. have reported that there was no alteration in the level of ATF4 in Sephin1-treated cells, but the level of pro-apoptotic CHOP protein was significantly decreased, preventing apoptotic cell death. Importantly, in comparison with GBZ, Sephin1 did not have $\alpha 2$-adrenergic activity. There were also no adverse effects on general health and memory 
observed in Sephin1-treated mice. Moreover, Sephin1 prevented motor neuron deficits and myelin thickness around axons in sciatic nerves in the mouse model (MPZ ${ }^{\text {mutant }}$ ) of demyelinating neuropathy Charcot-Marie-Tooth 1B. Moreover, loss of motor neurons was inhibited in transgenic mice expressing the human ALS-causing mutant SOD1G93A (SOD1 ${ }^{\text {mutant }}$ ), treated with Sephin1 [284]. Recently, this above-mentioned molecular mechanism, inhibited upon treatment of cells with activated ER stress conditions with Sephin1, was questioned by Crespillo-Casado et al. Surprisingly, investigation by Crespillo-Casado and colleagues demonstrated that Sephin1's ability to suppress neurodegeneration was not due to the inhibition of eIF2 $\alpha$ dephosphorylation via abrogation of GADD34-PP1C complex assembly. Thus, additional studies are necessary to discover alternative mechanisms that are responsible for Sephin1-mediated suppression of neurodegeneration [285].

\subsection{Trazodone Hydrochloride and Dibenzoylmethane}

The National Institute of Neurological Disorders and Stroke (NINDS) small-molecule library screening has identified two compounds with neuroprotective activity: trazodone hydrochloride and dibenzoylmethane (DBM). Trazodone is a well-known multi-target drug that belongs to the class of both serotonin receptor antagonists and reuptake inhibitors (SARIs) and serotonin type $2\left(5-\mathrm{HT}_{2 \mathrm{~A}}\right.$ and $5-\mathrm{HT}_{2 \mathrm{C}}$ ) receptor antagonists [286]. Due to its dual mechanism of action, it is capable of overcoming the adverse effects and tolerability issues associated with selective serotonin reuptake inhibitors (SSRIs) or serotonin-norepinephrine reuptake inhibitor (SNRI) therapy. In addition, trazodone exerts an antagonistic effect against histamine-H1, $\alpha 1$-adrenergic and $\alpha 2$-adrenergic receptors, as well as minimal anticholinergic activity [287]. For this reason, it has been widely used not only as an antidepressant, but also in treatment of numerous medical conditions including insomnia, posttraumatic stress disorder, obsessive compulsive or anxiety disorders, feeding and eating disorders, substance abuse, behavioral disturbances associated with cognitive dysfunction, fibromyalgia, and neuropathic pain [288]. A study by Halliday et al. demonstrated that both of the mentioned compounds possess the ability to significantly inhibit the p-eIF $2 \alpha$-dependent repression of global protein synthesis. Treatment with trazodone hydrochloride and DBM prion-infected mice prevented loss of hippocampal neurons, restored memory deficits, abrogated development of neurological signs, and markedly prolonged mice survival. Moreover, in an animal model of tauopathy-FTD, the tested small-molecule compounds rescued memory deficits and significantly reduced loss of hippocampal neurons. Importantly, both compounds are non-toxic to the pancreas and are characterized by good pharmacokinetic properties [279].

\section{8. $L D N-0060609$}

The newest data have reported that the small-molecule inhibitor of the PERK-dependent signaling pathway LDN-0060609, selected from the Laboratory for Drug Discovery in Neurodegeneration (LDDN) compound library, may constitute a novel, ground-breaking treatment strategy against neurodegenerative diseases, especially AD. It has been demonstrated that LDN-0060609 is non-cytotoxic, has no effect on cell cycle progression, and evokes a significant inhibition of the eIF $2 \alpha$ phosphorylation in the phenotype of type 1 rat normal astrocytes derived from diencephalon (DI TNC1) cell line. Thereby, LDN-0060609 significantly attenuates the pro-apoptotic, PERK-mediated signalling pathway and enhances cell survival in vitro; thus, it may contribute to prevention of apoptosis and the resulting neurodegeneration in terms of AD. However, the actual mechanism of action of the inhibitor is yet to be identified. It would also be intriguing to investigate whether this mentioned compound in fact exerts neuroprotective effects in animal models of not only AD but also other neurodegenerative diseases, including PD, ALS, and prion disease [289].

\subsection{Oxyresveratrol}

Resveratrol with its two analogues, oxyresveratrol (OXY) and piceatannol (PINO), are polyphenolic stilbenes derived from mulberry (Morus alba) fruits, already known to exert antioxidant and neuroprotective effects [290]. Among all three compounds, PINO has been confirmed to have 
the strongest anti-amyloidogenic properties in an AD in vitro model, wherein it decrease A $\beta$ levels via activation of $\alpha$-secretase and MMP-9, without inducing cell death [291]. Moreover, recently a novel, self-microemulsifying formulation of OXY appeared to be effective against $A \beta$ aggregation in an AD murine model, as well as resulting in a significant dose reduction due to higher bioavailability [292]. In PC12 cells, a common model for both AD and PD, PINO inhibited A $\beta$-induced ROS generation and apoptosis, $\alpha$-syn fibril formation, and $\alpha$-syn-induced cytotoxicity [293,294]. Interestingly, a recent study by Shah et al. revealed that the underlying mechanism of action of OXY is strictly correlated with the PERK-dependent UPR signaling pathway. In 6-OHDA-exposed Mes23.5 cells, one of the in vitro PD models, treatment with OXY significantly prevented the transcription of ATF4 with its main downstream target, $\mathrm{CHOP}$, even at the lowest concentration of the drug. In the second cellular model of PD, SH-SY5Y cells overexpressing A30P mutant $\alpha$-syn, OXY restored the increased level of another UPR-related protein, GRP78. However, the direct impact of OXY on CHOP-associated apoptosis as well as on the other branches of the UPR signaling pathway needs to be further elucidated [295].

\subsection{0. $\beta$-Asarone}

Numerous in vivo studies have confirmed the positive effects of application of asarone derivatives, such as $\alpha$ - or $\beta$-asarone, on cognitive function and alleviation of $A D$ symptoms in animal models [296-298]. Anti-amyloidogenic properties of mentioned compounds have also been observed in the PC12 cell line, and likewise an anti-neuroinflammatory effect in BV2 microglial cells [299]. Recently, it has been discovered that $\beta$-asarone improved behavioral functioning of 6-OHDA-induced parkinsonian rats. $\beta$-Asarone inhibited the expression of GRP78, CHOP, $\mathrm{p}$-IRE1 $\alpha$, and XBP1 within neurons, suggesting that its possible mechanism of action depends on two major UPR-related pathways, PERK- and IRE1 $\alpha$-dependent pathways [300]. Recent investigation on the same animal model have revealed that treatment of rats with $\beta$-asarone inhibited the PERK/CHOP/Bcl-2/Beclin- 1 axis with simultaneous downregulation of GRP78 and upregulation of Bcl-2. These results imply the key role of $\beta$-asarone in regulation of ER stress-associated autophagy, and they were consistent with the ones obtained in the PERK inhibitor-treated group [301].

\subsection{Gastrodia Elata Derivatives}

Numerous compounds have been extracted from Gastrodia elata Blume (GE), a traditional herbal medicine, and their antioxidant properties have been under detailed investigation. Gastrodin (Gas) has been found to suppress BACE1 expression in Tg2576 mice and $\mathrm{H}_{2} \mathrm{O}_{2}$-stimulated SH-SY5Y cells via inhibition of PKR and eIF2 $\alpha$ activation. The downregulation of BACE1 resulted in improvement in learning and memory abilities in treated mice as well as it attenuated oxidative stress in hippocampus on the molecular level. However, it has been suggested that Gas-induced inhibition of eIF2 $\alpha$ phosphorylation was independent from PERK activation [302]. In another study, GE and its two components, Gas and 4-hydroxybenzyl alcohol (4HBA), were shown to prevent BV2 mouse microglial cells from $A \beta$-induced cell death via inhibition of $C H O P$-mediated branch with simultaneous upregulation of GRP78 chaperones [303]. On the contrary, bibenzyl compound 20C, a novel compound isolated from GE, has been demonstrated to protect PC12 cells against tunicamycin-induced ER stress. Co-treatment of cells with 20C induced suppression of all three UPR-related signaling branches, including the PERK-dependent one. It has been demonstrated that the levels of p-eIF2 $\alpha$ and ATF4 were significantly decreased. Moreover, $20 \mathrm{C}$ reduced the accumulation of $\alpha$-syn within cells concurrently, which further improved the cell viability [304]. In a separate experiment, it was found that 20C attenuated apoptosis and oxidative stress in rotenone-treated PC12 cells via activation of the nuclear factor erythroid 2-related factor 2 (Nrf2)/antioxidant responsive element (ARE)/heme oxygenase-1 (HO-1) signaling pathway, which is strictly correlated with the PERK-mediated branch of the UPR signaling pathway [305]. With regard to all these aspects, the actual mechanism of action of GE and its derivatives is yet to be confirmed (Figure 2). 


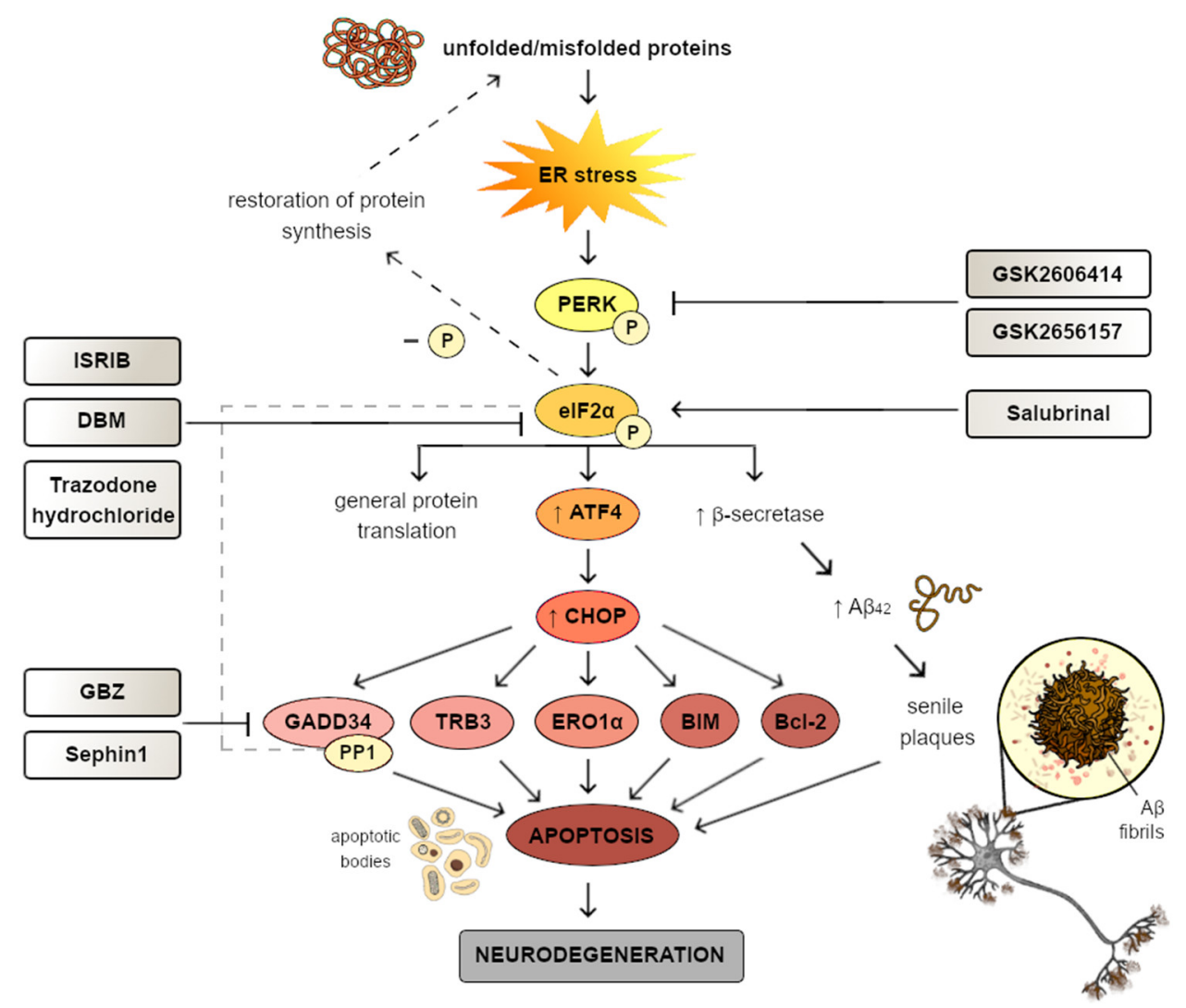

Figure 2. Small-molecule inhibitors of the protein kinase RNA-like endoplasmic reticulum kinase (PERK)-dependent UPR signaling pathway and their targets of action. Numerous studies have suggested that the pathogenesis of neurodegenerative diseases, including Alzheimer's disease (AD), is correlated with the accumulation of misfolded and unfolded proteins, which may directly or indirectly trigger endoplasmic reticulum (ER) stress conditions and activation of the PERK-dependent unfolded protein response (UPR) signaling pathways. The upregulation of specific mechanisms related to the PERK branch of UPR signaling and AD pathogenesis is indicated by arrow, downregulation by inhibiting line, whereas GADD34-mediated dephosphorylation of eIF2 $\alpha$ in a negative feedback loop by dotted arrow. Under mild-to-moderate ER stress conditions, UPR has a pro-adaptive role, whereas severe or long-termed ER stress conditions directly evoke shift of the UPR toward its pro-apoptotic branch, leading to neurodegeneration. The newest data have reported that pharmacological modulation of the PERK-dependent branch of the UPR signaling pathway via small-molecule inhibitors may constitute a novel treatment strategy against neurodegeneration.

\section{Summary and Perspective}

As previously indicated, the pathogenesis of a broad range of neurodegenerative diseases in most cases may be correlated with common molecular process, namely, aggregation of misfolded and unfolded proteins within the nervous tissue. Nevertheless, the role of the PERK-dependent UPR signaling branch in the process of neurodegeneration still remains controversial. There are many contradictory results described in the literature, even in cases where researchers referred to similar issues or the studies were conducted on the same disease models. It needs to be clarified whether the ER stress conditions and subsequent activation of the PERK branch are evoked by accumulation of protein aggregates within neurons (tau, $\alpha$-syn, $\left.\mathrm{mHtt}, \mathrm{PrP}^{\mathrm{Sc}}\right)$ or surrounding nervous tissue ( $\mathrm{A} \beta$, $\left.\operatorname{PrP}^{\mathrm{Sc}}\right)$, as one report may indicate that they indeed are activated, whereas others state that they are not. To fully address this issue, it is recommended that the studies be repeated with particular emphasis on the improvement of currently used experimental methods. Another problem to be resolved appears to be the mechanism in which disturbances in the ER, as reported in numerous 
proteopathies, are actually induced, considering the fact that most of mentioned proteins are not strictly associated with the ER lumen and they rather accumulate in the cytoplasm or extracellularly. Although the molecular mechanism that evokes shift of the UPR from pro-adaptive toward pro-apoptotic still remains unclear, there is a plethora of studies that have demonstrated that inhibition of the PERK-dependent UPR signaling pathways may constitute a novel, ground-breaking treatment strategy against neurodegenerative diseases. Numerous studies have confirmed the neuroprotective effect of targeting this particular branch in various types and models of neurodegenerative disorders. However, there is still missing data on many aspects of such therapeutic interventions, as well as lack of in vivo studies, as all the potential adverse effects should be taken into consideration. In addition, the actual mechanism of action of numerous potential PERK inhibitors also needs to be clarified, as their impact on the other two branches of the UPR as well as crosstalk between them and other signaling pathways remain elusive and not fully understood. Moreover, the results of studies on neurodegeneration that required the use of GSK inhibitors may be in fact irrelevant, as it has been proven that both inhibitors are more prone to inhibit the RIPK1-dependent apoptotic pathway rather than PERK. It should also be kept in mind that the mechanism of action of currently used PERK inhibitors is often based on selective inhibition of eIF $2 \alpha$ phosphorylation, which constitutes the target of other kinases as well. Therefore, it is highly necessary to perform research on recently developed inhibitors such as AMG'44, which are both highly selective for PERK and their potential has not been fully elucidated in terms of neurodegenerative diseases. To sum up, further investigation needs to be done with regards to all mentioned issues. A thorough understanding of molecular processes involved in the pathomechanism of neurodegeneration is the key to develop an optimized, targeted therapeutic approach against all the mentioned (yet) incurable diseases.

Author Contributions: Conception and literature review: W.R.-K., N.S., A.W., D.P., I.M.; writing一original draft preparation: W.R.-K., N.S., A.W., R.W.; writing—review and editing: I.M., D.P., J.A.D.; preparation of illustrations: N.S., W.R.-K. The Figure 1 was created with BioRender.com. All authors have read and agreed to the published version of the manuscript.

Funding: This work was supported by grant PRELUDIUM no. 2015/19/N/NZ3/00055 from the Polish National Science Centre; by grant OPUS no. 2016/21/B/NZ5/01411 from the Polish National Science Centre; by grant OPUS no. 2017/27/B/NZ7/02527 from the Polish National Science Centre; by grant HARMONIA no. 2013/10/M/NZ1/00280 from the Polish National Science Centre; and by grants of Medical University of Lodz, Poland, no. 502-03/5-108-05/502-54-224-18, 564/5-000-00/564-20-035, and 564/5-000-00/564-20-038.

Conflicts of Interest: The authors declare no conflict of interest.

\section{References}

1. Brown, R.C.; Lockwood, A.H.; Sonawane, B.R. Neurodegenerative diseases: An overview of environmental risk factors. Environ. Health Perspect. 2005, 113, 1250-1256. [CrossRef] [PubMed]

2. Skoog, I.; Börjesson-Hanson, A.; Kern, S.; Johansson, L.; Falk, H.; Sigström, R.; Östling, S. Decreasing prevalence of dementia in 85-year olds examined 22 years apart: The influence of education and stroke. Sci. Rep. 2017, 7, 1-8. [CrossRef] [PubMed]

3. Prince, M.; Bryce, R.; Albanese, E.; Wimo, A.; Ribeiro, W.; Ferri, C.P. The Global Prevalence of Dementia: A Systematic Review and Metaanalysis. Alzheimers Dement. 2013, 9, 63-75. [CrossRef] [PubMed]

4. Babusikova, E.; Evinova, A.; Jurecekova, J.; Jesenak, M.; Dobrot, D. Alzheimer's Disease: Definition, Molecular and Genetic Factors. In Advanced Understanding of Neurodegenerative Diseases; IntechOpen: London, UK, 2011.

5. Krantic, S. Editorial Thematic Issue: From Current Diagnostic Tools and Therapeutics for Alzheimer's Disease towards Earlier Diagnostic Markers and Treatment Targets. Curr. Alzheimer Res. 2016, 14, 2-5. [CrossRef] [PubMed]

6. Wortmann, M. Dementia: A global health priority-Highlights from an ADI and World Health Organization report. Alzheimer's Res. Ther. 2012, 4, 40. [CrossRef] [PubMed]

7. Van Ham, T.J.; Breitling, R.; Swertz, M.A.; Nollen, E.A.A.A. Neurodegenerative diseases: Lessons from genome-wide screens in small model organisms. EMBO Mol. Med. 2009, 1, 360-370. [CrossRef] 
8. Brundin, P.; Melki, R.; Kopito, R. Prion-like transmission of protein aggregates in neurodegenerative diseases. Nat. Rev. Mol. Cell Biol. 2010, 11, 301-307. [CrossRef] [PubMed]

9. Elharram, A.; Czegledy, N.M.; Golod, M.; Milne, G.L.; Pollock, E.; Bennett, B.M.; Shchepinov, M.S. Deuterium-reinforced polyunsaturated fatty acids improve cognition in a mouse model of sporadic Alzheimer's disease. FEBS J. 2017, 284, 4083-4095. [CrossRef]

10. Raefsky, S.M.; Furman, R.; Milne, G.; Pollock, E.; Axelsen, P.; Mattson, M.P.; Shchepinov, M.S. Deuterated polyunsaturated fatty acids reduce brain lipid peroxidation and hippocampal amyloid $\beta$-peptide levels, without discernable behavioral effects in an APP/PS1 mutant transgenic mouse model of Alzheimer's disease. Neurobiol. Aging 2018, 66, 165-176. [CrossRef]

11. Shchepinov, M.S.; Chou, V.P.; Pollock, E.; Langston, J.W.; Cantor, C.R.; Molinari, R.J.; Manning-Boĝ, A.B. Isotopic reinforcement of essential polyunsaturated fatty acids diminishes nigrostriatal degeneration in a mouse model of Parkinson's disease. Toxicol. Lett. 2011, 207, 97-103. [CrossRef]

12. Hatami, A.; Zhu, C.; Relaño-Gines, A.; Elias, C.; Galstyan, A.; Jun, M.; Milne, G.; Cantor, C.R.; Chesselet, M.F.; Shchepinov, M.S. Deuterium-reinforced linoleic acid lowers lipid peroxidation and mitigates cognitive impairment in the Q140 knock in mouse model of Huntington's disease. FEBS J. 2018, 285, 3002-3012. [CrossRef] [PubMed]

13. Halliday, M.; Mallucci, G.R. Review: Modulating the unfolded protein response to prevent neurodegeneration and enhance memory. Neuropathol. Appl. Neurobiol. 2015, 41, 414-427. [CrossRef] [PubMed]

14. Rozpedek, W.; Markiewicz, L.; Diehl, J.; Pytel, D.; Majsterek, I. Unfolded Protein Response and PERK Kinase as a New Therapeutic Target in the Pathogenesis of Alzheimer's Disease. Curr. Med. Chem. 2015, 22, 3169-3184. [CrossRef] [PubMed]

15. Paraskevaidi, M.; Morais, C.L.M.; Lima, K.M.G.; Snowden, J.S.; Saxon, J.A.; Richardson, A.M.T.; Jones, M.; Mann, D.M.A.; Allsop, D.; Martin-Hirsch, P.L.; et al. Differential diagnosis of Alzheimer's disease using spectrochemical analysis of blood. Proc. Natl. Acad. Sci. USA 2017, 114, E7929-E7938. [CrossRef]

16. Rocca, W.A.; Petersen, R.C.; Knopman, D.S.; Hebert, L.E.; Evans, D.A.; Hall, K.S.; Gao, S.; Unverzagt, F.W.; Langa, K.M.; Larson, E.B.; et al. Trends in the incidence and prevalence of Alzheimer's disease, dementia, and cognitive impairment in the United States. Alzheimer's Dement. 2011, 7, 80-93. [CrossRef]

17. Van Giau, V.; Pyun, J.M.; Suh, J.; Bagyinszky, E.; An, S.S.A.; Kim, S.Y. A pathogenic PSEN1 Trp165Cys mutation associated with early-onset Alzheimer's disease. BMC Neurol. 2019, 19, 188. [CrossRef]

18. Meraz-Ríos, M.A.; Franco-Bocanegra, D.; Toral Rios, D.; Campos-Peña, V. Early onset Alzheimer's disease and oxidative stress. Oxidative Med. Cell. Longev. 2014, 2014. [CrossRef]

19. Snowden, S.G.; Ebshiana, A.A.; Hye, A.; An, Y.; Pletnikova, O.; O’Brien, R.; Troncoso, J.; Legido-Quigley, C.; Thambisetty, M. Association between fatty acid metabolism in the brain and Alzheimer disease neuropathology and cognitive performance: A nontargeted metabolomic study. PLoS Med. 2017, 14, e1002266. [CrossRef]

20. Forchetti, C.M. Treating patients with moderate to severe Alzheimer's Disease: Implications of recent pharmacologic studies. Prim. Care Companion J. Clin. Psychiatry 2005, 7, 155-161. [CrossRef]

21. Holtzman, D.M.; Morris, J.C.; Goate, A.M. Alzheimer's disease: The challenge of the second century. Sci. Transl. Med. 2011, 3. [CrossRef]

22. Ferris, S.H.; Farlow, M. Language impairment in alzheimer's disease and benefits of acetylcholinesterase inhibitors. Clin. Interv. Aging 2013, 8, 1007-1014. [CrossRef] [PubMed]

23. Nisbet, R.M.; Polanco, J.C.; Ittner, L.M.; Götz, J. Tau aggregation and its interplay with amyloid- $\beta$. Acta Neuropathol. 2015, 129, 207-220. [CrossRef] [PubMed]

24. Liu, Y.; Qing, H.; Deng, Y. Biomarkers in Alzheimer's disease analysis by mass spectrometry-based proteomics. Int. J. Mol. Sci. 2014, 15, 7865-7882. [CrossRef] [PubMed]

25. Serrano-Pozo, A.; Frosch, M.P.; Masliah, E.; Hyman, B.T. Neuropathological alterations in Alzheimer disease. Cold Spring Harb. Perspect. Med. 2011, 1, a006189. [CrossRef] [PubMed]

26. Lacosta, A.M.; Insua, D.; Badi, H.; Pesini, P.; Sarasa, M. Neurofibrillary Tangles of A $\beta x-40$ in Alzheimer's Disease Brains. J. Alzheimer's Dis. 2017, 58, 661-667. [CrossRef]

27. Donev, R.; Kolev, M.; Millet, B.; Thome, J. Neuronal death in Alzheimer's disease and therapeutic opportunities. J. Cell. Mol. Med. 2009, 13, 4329-4348. [CrossRef]

28. Jahn, H. Memory loss in alzheimer's disease. Dialogues Clin. Neurosci. 2013, 15, 445-454. 
29. Salminen, A.; Kauppinen, A.; Suuronen, T.; Kaarniranta, K.; Ojala, J. ER stress in Alzheimer's disease: A novel neuronal trigger for inflammation and Alzheimer's pathology. J. Neuroinflamm. 2009, 6, 41. [CrossRef]

30. Rahman, S.; Archana, A.; Jan, A.T.; Minakshi, R. Dissecting endoplasmic reticulum unfolded protein response (UPRER) in managing clandestine modus operandi of Alzheimer's disease. Front. Aging Neurosci. 2018, 10, 30. [CrossRef]

31. Glabe, C. Intracellular mechanisms of amyloid accumulation and pathogenesis in Alzheimer's disease. J. Mol. Neurosci. 2001, 17, 137-145. [CrossRef]

32. Butterfield, D.A.; Swomley, A.M.; Sultana, R. Amyloid $\beta$-Peptide (1-42)-induced oxidative stress in alzheimer disease: Importance in disease pathogenesis and progression. Antioxid. Redox Signal. 2013, 19, 823-835. [CrossRef] [PubMed]

33. Nunan, J.; Small, D.H. Regulation of APP cleavage by $\alpha-, \beta$ - and $\gamma$-secretases. FEBS Lett. 2000, 483, 6-10. [CrossRef]

34. Khalifa, N.B.; Van Hees, J.; Tasiaux, B.; Huysseune, S.; Smith, S.O.; Constantinescu, S.N.; Octave, J.N.; Kienlen-Campard, P. What is the role of amyloid precursor protein dimerization? Cell Adhes. Migr. 2010, 4, 268-272. [CrossRef] [PubMed]

35. O’Brien, R.J.; Wong, P.C. Amyloid Precursor Protein Processing and Alzheimer's Disease. Annu. Rev. Neurosci. 2011, 34, 185-204. [CrossRef] [PubMed]

36. Weggen, S.; Beher, D. Molecular consequences of amyloid precursor protein and presenilin mutations causing autosomal-dominant Alzheimer's disease. Alzheimer's Res. Ther. 2012, 4, 9. [CrossRef] [PubMed]

37. De Strooper, B. Aph-1, Pen-2, and Nicastrin with Presenilin generate an active $\gamma$-Secretase complex. Neuron 2003, 38, 9-12. [CrossRef]

38. Hashimoto, Y.; Matsuoka, M. A mutation protective against Alzheimer's disease renders amyloid $\beta$ precursor protein incapable of mediating neurotoxicity. J. Neurochem. 2014, 130, 291-300. [CrossRef]

39. Portelius, E.; Price, E.; Brinkmalm, G.; Stiteler, M.; Olsson, M.; Persson, R.; Westman-Brinkmalm, A.; Zetterberg, H.; Simon, A.J.; Blennow, K. A novel pathway for amyloid precursor protein processing. Neurobiol. Aging 2011, 32, 1090-1098. [CrossRef]

40. Miras-Portugal, M.T.; Diaz-Hernandez, J.I.; Gomez-Villafuertes, R.; Diaz-Hernandez, M.; Artalejo, A.R.; Gualix, J. Role of P2X7 and P2Y2 receptors on $\alpha$-secretase-dependent APP processing: Control of amyloid plaques formation "in vivo" by P2X7 receptor. Comput. Struct. Biotechnol. J. 2015, 13, 176-181. [CrossRef]

41. Hicks, D.A.; Nalivaeva, N.N.; Turner, A.J. Lipid rafts and Alzheimer's disease: Protein-lipid interactions and perturbation of signaling. Front. Physiol. 2012, 3, 189. [CrossRef]

42. Zhang, S.; Wang, Z.; Cai, F.; Zhang, M.; Wu, Y.; Zhang, J.; Song, W. BACE1 cleavage site selection critical for amyloidogenesis and Alzheimer's pathogenesis. J. Neurosci. 2017, 37, 6915-6925. [CrossRef] [PubMed]

43. Mohandas, E.; Rajmohan, V.; Raghunath, B. Neurobiology of Alzheimer's disease. Indian J. Psychiatry 2009, 51, 55-61. [CrossRef] [PubMed]

44. Yang, L.B.; Lindholm, K.; Yan, R.; Citron, M.; Xia, W.; Yang, X.L.; Beach, T.; Sue, L.; Wong, P.; Price, D.; et al. Elevated $\beta$-secretase expression and enzymatic activity detected in sporadic Alzheimer disease. Nat. Med. 2003, 9, 3-4. [CrossRef] [PubMed]

45. Holsinger, R.M.D.; McLean, C.A.; Beyreuther, K.; Masters, C.L.; Evin, G. Increased expression of the amyloid precursor $\beta$-secretase in Alzheimer's disease. Ann. Neurol. 2002, 51, 783-786. [CrossRef] [PubMed]

46. Fukumoto, H.; Cheung, B.S.; Hyman, B.T.; Irizarry, M.C. $\beta$-secretase protein and activity are increased in the neocortex in Alzheimer disease. Arch. Neurol. 2002, 59, 1381-1389. [CrossRef] [PubMed]

47. O'Connor, T.; Sadleir, K.R.; Maus, E.; Velliquette, R.A.; Zhao, J.; Cole, S.L.; Eimer, W.A.; Hitt, B.; Bembinster, L.A.; Lammich, S.; et al. Phosphorylation of the Translation Initiation Factor eIF2 $\alpha$ Increases BACE1 Levels and Promotes Amyloidogenesis. Neuron 2008, 60, 988-1009. [CrossRef] [PubMed]

48. Hoozemans, J.J.M.; Van Haastert, E.S.; Nijholt, D.A.T.; Rozemuller, A.J.M.; Eikelenboom, P.; Scheper, W. The unfolded protein response is activated in pretangle neurons in alzheimer's disease hippocampus. Am. J. Pathol. 2009, 174, 1241-1251. [CrossRef]

49. Stutzbach, L.D.; Xie, S.X.; Naj, A.C.; Albin, R.; Gilman, S.; Lee, V.M.Y.; Trojanowski, J.Q.; Devlin, B.; Schellenberg, G.D. The unfolded protein response is activated in disease-affected brain regions in progressive supranuclear palsy and Alzheimer's disease. Acta Neuropathol. Commun. 2014, 2, 31. [CrossRef]

50. Li, Y.; Guo, Y.; Tang, J.; Jiang, J.; Chen, Z. New insights into the roles of CHOP-induced apoptosis in ER stress. Acta Biochim. Biophys. Sin. 2014, 46, 629-640. [CrossRef] 
51. Sadleir, K.R.; Popovic, J.; Vassar, R. ER stress is not elevated in the 5XFAD mouse model of Alzheimer's disease. J. Biol. Chem. 2018, 293, 18434-18443. [CrossRef]

52. Spatara, M.L.; Robinson, A.S. Transgenic mouse and cell culture models demonstrate a lack of mechanistic connection between endoplasmic reticulum stress and tau dysfunction. J. Neurosci. Res. 2010, 88, 1951-1961. [CrossRef] [PubMed]

53. Pitera, A.P.; Asuni, A.A.; O'Connor, V.; Deinhardt, K. Pathogenic tau does not drive activation of the unfolded protein response. J. Biol. Chem. 2019, 294, 9679-9688. [CrossRef] [PubMed]

54. Ohno, M. PERK as a hub of multiple pathogenic pathways leading to memory deficits and neurodegeneration in Alzheimer's disease. Brain Res. Bull. 2018, 141, 72-78. [CrossRef] [PubMed]

55. Ray Dorsey, E.; Elbaz, A.; Nichols, E.; Abd-Allah, F.; Abdelalim, A.; Adsuar, J.C.; Ansha, M.G.; Brayne, C.; Choi, J.Y.J.; Collado-Mateo, D.; et al. Global, regional, and national burden of Parkinson's disease, 1990-2016: A systematic analysis for the Global Burden of Disease Study 2016. Lancet Neurol. 2018, 17, 939-953. [CrossRef]

56. Calabrese, V.P. Projected number of people with Parkinson disease in the most populous nations, 2005 through 2030. Neurology 2007, 68, 384-386. [CrossRef]

57. Poewe, W.; Seppi, K.; Tanner, C.M.; Halliday, G.M.; Brundin, P.; Volkmann, J.; Schrag, A.E.; Lang, A.E. Parkinson disease. Nat. Rev. Dis. Prim. 2017, 3, 1-21. [CrossRef]

58. Mercado, G.; Castillo, V.; Vidal, R.; Hetz, C. ER proteostasis disturbances in Parkinson's disease: Novel insights. Front. Aging Neurosci. 2015, 7, 39. [CrossRef]

59. Valdés, P.; Mercado, G.; Vidal, R.L.; Molina, C.; Parsons, G.; Court, F.A.; Martinez, A.; Galleguillos, D.; Armentano, D.; Schneider, B.L.; et al. Control of dopaminergic neuron survival by the unfolded protein response transcription factor XBP1. Proc. Natl. Acad. Sci. USA 2014, 111, 6804-6809. [CrossRef]

60. Driver, J.A.; Logroscino, G.; Gaziano, J.M.; Kurth, T. Incidence and remaining lifetime risk of Parkinson disease in advanced age. Neurology 2009, 72, 432-438. [CrossRef]

61. Ascherio, A.; Schwarzschild, M.A. The epidemiology of Parkinson's disease: Risk factors and prevention. Lancet Neurol. 2016, 15, 1257-1272. [CrossRef]

62. Kim, C.Y.; Alcalay, R.N. Genetic Forms of Parkinson's Disease. Semin. Neurol. 2017, 37, 135-146. [CrossRef] [PubMed]

63. Mercado, G.; Castillo, V.; Soto, P.; Sidhu, A. ER stress and Parkinson's disease: Pathological inputs that converge into the secretory pathway. Brain Res. 2016, 1648, 626-632. [CrossRef] [PubMed]

64. Lehtonen, Š.; Sonninen, T.M.; Wojciechowski, S.; Goldsteins, G.; Koistinaho, J. Dysfunction of cellular proteostasis in Parkinson's disease. Front. Neurosci. 2019, 13, 457. [CrossRef] [PubMed]

65. Vaya, J.; Aluf, Y.; Finberg, J.P.M. Oxidative Stress in Parkinson's Disease. In Oxidative Stress and Free Radical Damage in Neurology; Humana Press: Totowa, NJ, USA, 2011; pp. 191-223.

66. Puspita, L.; Chung, S.Y.; Shim, J.W. Oxidative stress and cellular pathologies in Parkinson's disease. Mol. Brain 2017, 10, 53. [CrossRef] [PubMed]

67. Cifu, D.X.; Eapen, B.C.; Janak, J.C.; Pugh, M.J.; Orman, J.A.L. Epidemiology of traumatic brain injury. In Traumatic Brain Injury Rehabilitation Medicine; Future Medicine Ltd.: London, UK, 2015; pp. 6-35.

68. Gardner, R.C.; Byers, A.L.; Barnes, D.E.; Li, Y.; Boscardin, J.; Yaffe, K. Mild TBI and risk of Parkinson disease: A Chronic Effects of Neurotrauma Consortium Study. Neurology 2018, 90, E1771-E1779. [CrossRef] [PubMed]

69. Pozo Devoto, V.M.; Falzone, T.L. Mitochondrial dynamics in Parkinson's disease: A role for $\alpha$-synuclein? DMM Dis. Model. Mech. 2017, 10, 1075-1087. [CrossRef] [PubMed]

70. Grosch, J.; Winkler, J.; Kohl, Z. Early degeneration of both dopaminergic and serotonergic axons-A common mechanism in parkinson's disease. Front. Cell. Neurosci. 2016, 10, 293. [CrossRef]

71. Varrone, A.; Halldin, C. Molecular imaging of the dopamine transporter. J. Nucl. Med. 2010, 51, 1331-1334. [CrossRef]

72. Fields, C.R.; Bengoa-Vergniory, N.; Wade-Martins, R. Targeting Alpha-Synuclein as a Therapy for Parkinson's Disease. Front. Mol. Neurosci. 2019, 12, 299. [CrossRef]

73. Perri, E.R.; Thomas, C.J.; Parakh, S.; Spencer, D.M.; Atkin, J.D. The unfolded protein response and the role of protein disulfide isomerase in neurodegeneration. Front. Cell Dev. Biol. 2016, 3, 80. [CrossRef]

74. Doyle, K.M.; Kennedy, D.; Gorman, A.M.; Gupta, S.; Healy, S.J.M.; Samali, A. Unfolded proteins and endoplasmic reticulum stress in neurodegenerative disorders. J. Cell. Mol. Med. 2011, 15, 2025-2039. [CrossRef] [PubMed] 
75. De Pablo-Fernandez, E.; Tur, C.; Revesz, T.; Lees, A.J.; Holton, J.L.; Warner, T.T. Association of autonomic dysfunction with disease progression and survival in Parkinson disease. JAMA Neurol. 2017, 74, 970-976. [CrossRef]

76. Bhardwaj, R.; Deshmukh, R. Parkinson's Disease: An Insight into Mechanisms and Model Systems. Int. J. Med. Res. Health Sci. 2018, 7, 38-51.

77. Volpicelli-Daley, L.; Brundin, P. Prion-like propagation of pathology in Parkinson disease. In Handbook of Clinical Neurology; Elsevier: Amsterdam, The Netherlands, 2018; Volume 153, pp. 321-335. ISBN 9780444639455.

78. Fullard, M.E.; Morley, J.F.; Duda, J.E. Olfactory Dysfunction as an Early Biomarker in Parkinson's Disease. Neurosci. Bull. 2017, 33, 515-525. [CrossRef]

79. Floor, E.; Wetzel, M.G. Increased Protein Oxidation in Human Substantia Nigra Pars Compacta in Comparison with Basal Ganglia and Prefrontal Cortex Measured with an Improved Dinitrophenylhydrazine Assay. J. Neurochem. 2002, 70, 268-275. [CrossRef]

80. Nikolova, G. Oxidative stress and Parkinson disease. TRAKIA J. Sci. 2012, 10, 92-100.

81. Bourdenx, M.; Koulakiotis, N.S.; Sanoudou, D.; Bezard, E.; Dehay, B.; Tsarbopoulos, A. Protein aggregation and neurodegeneration in prototypical neurodegenerative diseases: Examples of amyloidopathies, tauopathies and synucleinopathies. Prog. Neurobiol. 2017, 155, 171-193. [CrossRef]

82. Shimozawa, A.; Ono, M.; Takahara, D.; Tarutani, A.; Imura, S.; Masuda-Suzukake, M.; Higuchi, M.; Yanai, K.; Hisanaga, S.I.; Hasegawa, M. Propagation of pathological $\alpha$-synuclein in marmoset brain. Acta Neuropathol. Commun. 2017, 5, 12. [CrossRef]

83. Singleton, A.B.; Farrer, M.; Johnson, J.; Singleton, A.B.; Hague, S.; Kachergus, J.; Hulihan, M.; Peuralinna, T.; Dutra, A.; Nussbaum, R.; et al. $\alpha$-Synuclein Locus Triplication Causes Parkinson's Disease. Science 2003, 302, 841. [CrossRef] [PubMed]

84. Visanji, N.P.; Lang, A.E.; Kovacs, G.G. Beyond the synucleinopathies: Alpha synuclein as a driving force in neurodegenerative comorbidities. Transl. Neurodegener. 2019, 8, 1-13. [CrossRef] [PubMed]

85. Martinez, A.; Lopez, N.; Gonzalez, C.; Hetz, C. Targeting of the unfolded protein response (UPR) as therapy for Parkinson's disease. Biol. Cell 2019, 111, 161-168. [CrossRef]

86. Bertoncini, C.W.; Jung, Y.S.; Fernandez, C.O.; Hoyer, W.; Griesinger, C.; Jovin, T.M.; Zweckstetter, M. Release of long-range tertiary interactions potentiates aggregation of natively unstructured $\alpha$-synuclein. Proc. Natl. Acad. Sci. USA 2005, 102, 1430-1435. [CrossRef]

87. Stefani, C.I.; Wright, D.; Polizzi, M.K.; Kontoravdi, C. The Role of ER Stress-Induced Apoptosis in Neurodegeneration. Curr. Alzheimer Res. 2012, 9, 373-387. [CrossRef] [PubMed]

88. Anderson, J.P.; Walker, D.E.; Goldstein, J.M.; De Laat, R.; Banducci, K.; Caccavello, R.J.; Barbour, R.; Huang, J.; Kling, K.; Lee, M.; et al. Phosphorylation of Ser-129 is the dominant pathological modification of $\alpha$-synuclein in familial and sporadic lewy body disease. J. Biol. Chem. 2006, 281, 29739-29752. [CrossRef] [PubMed]

89. Colla, E. Linking the endoplasmic reticulum to Parkinson's disease and alpha-synucleinopathy. Front. Neurosci. 2019, 13, 560. [CrossRef] [PubMed]

90. Cooper, A.A.; Gitler, A.D.; Cashikar, A.; Haynes, C.M.; Hill, K.J.; Bhullar, B.; Liu, K.; Xu, K.; Strathearn, K.E.; Liu, F.; et al. $\alpha$-synuclein blocks ER-Golgi traffic and Rab1 rescues neuron loss in Parkinson's models. Science 2006, 313, 324-328. [CrossRef] [PubMed]

91. Mazzulli, J.R.; Zunke, F.; Isacson, O.; Studer, L.; Krainc, D. $\alpha$-Synuclein-induced lysosomal dysfunction occurs through disruptions in protein trafficking in human midbrain synucleinopathy models. Proc. Natl. Acad. Sci. USA 2016, 113, 1931-1936. [CrossRef]

92. Credle, J.J.; Forcelli, P.A.; Delannoy, M.; Oaks, A.W.; Permaul, E.; Berry, D.L.; Duka, V.; Wills, J.; Sidhu, A. $\alpha$-Synuclein-mediated inhibition of ATF6 processing into COPII vesicles disrupts UPR signaling in Parkinson's disease. Neurobiol. Dis. 2015, 76, 112-125. [CrossRef]

93. Betzer, C.; Lassen, L.B.; Olsen, A.; Kofoed, R.H.; Reimer, L.; Gregersen, E.; Zheng, J.; Calì, T.; Gai, W.; Chen, T.; et al. Alpha-synuclein aggregates activate calcium pump SERCA leading to calcium dysregulation. EMBO Rep. 2018, 19. [CrossRef]

94. Paiva, I.; Jain, G.; Lázaro, D.F.; Jerčić, K.G.; Hentrich, T.; Kerimoglu, C.; Pinho, R.; Szegő, È.M.; Burkhardt, S.; Capece, V.; et al. Alpha-synuclein deregulates the expression of COL4A2 and impairs ER-Golgi function. Neurobiol. Dis. 2018, 119, 121-135. [CrossRef] 
95. Bellucci, A.; Navarria, L.; Zaltieri, M.; Falarti, E.; Bodei, S.; Sigala, S.; Battistin, L.; Spillantini, M.; Missale, C.; Spano, P. Induction of the unfolded protein response by $\alpha$-synuclein in experimental models of Parkinson's disease. J. Neurochem. 2011, 116, 588-605. [CrossRef] [PubMed]

96. Bellani, S.; Mescola, A.; Ronzitti, G.; Tsushima, H.; Tilve, S.; Canale, C.; Valtorta, F.; Chieregatti, E. GRP78 clustering at the cell surface of neurons transduces the action of exogenous alpha-synuclein. Cell Death Differ. 2014, 21, 1971-1983. [CrossRef] [PubMed]

97. Lee, H.; Noh, J.Y.; Oh, Y.; Kim, Y.; Chang, J.W.; Chung, C.W.; Lee, S.T.; Kim, M.; Ryu, H.; Jung, Y.K. IRE1 plays an essential role in ER stress-mediated aggregation of mutant huntingtin via the inhibition of autophagy flux. Hum. Mol. Genet. 2012, 21, 101-114. [CrossRef] [PubMed]

98. Vidal, R.; Caballero, B.; Couve, A.; Hetz, C. Converging Pathways in the Occurrence of Endoplasmic Reticulum (ER) Stress in Huntingtons Disease. Curr. Mol. Med. 2011, 11, 1-12. [CrossRef] [PubMed]

99. Illarioshkin, S.N.; Klyushnikov, S.A.; Vigont, V.A.; Seliverstov, Y.A.; Kaznacheyeva, E.V. Molecular Pathogenesis in Huntington's Disease. Biochemistry 2018, 83, 1030-1039. [CrossRef]

100. Zuleta, A.; Vidal, R.L.; Armentano, D.; Parsons, G.; Hetz, C. AAV-mediated delivery of the transcription factor XBP1s into the striatum reduces mutant Huntingtin aggregation in a mouse model of Huntington's disease. Biochem. Biophys. Res. Commun. 2012, 420, 558-563. [CrossRef] [PubMed]

101. Xiang, C.; Wang, Y.; Zhang, H.; Han, F. The role of endoplasmic reticulum stress in neurodegenerative disease. Apoptosis 2017, 22, 1-26. [CrossRef]

102. Margulis, J.; Finkbeiner, S. Proteostasis in striatal cells and selective neurodegeneration in Huntington's disease. Front. Cell. Neurosci. 2014, 8, 218. [CrossRef]

103. Shacham, T.; Sharma, N.; Lederkremer, G.Z. Protein misfolding and ER stress in Huntington's disease. Front. Mol. Biosci. 2019, 6, 20. [CrossRef]

104. Valionyte, E.; Yang, Y.; Roberts, S.L.; Kelly, J.; Lu, B.; Luo, S. Lowering Mutant Huntingtin Levels and Toxicity: Autophagy-Endolysosome Pathways in Huntington's Disease. J. Mol. Biol. 2019. [CrossRef]

105. Jiang, Y.; Chadwick, S.R.; Lajoie, P. Endoplasmic reticulum stress: The cause and solution to Huntington's disease? Brain Res. 2016, 1648, 650-657. [CrossRef] [PubMed]

106. Park, K.W.; Eun Kim, G.; Morales, R.; Moda, F.; Moreno-Gonzalez, I.; Concha-Marambio, L.; Lee, A.S.; Hetz, C.; Soto, C. The Endoplasmic Reticulum Chaperone GRP78/BiP Modulates Prion Propagation in vitro and in vivo. Sci. Rep. 2017, 7, 44723. [CrossRef]

107. Scheper, W.; Hoozemans, J.J.M. The unfolded protein response in neurodegenerative diseases: A neuropathological perspective. Acta Neuropathol. 2015, 130, 315-331. [CrossRef] [PubMed]

108. Kanemoto, S. Targeting the endoplasmic reticulum in prion disease treatment: Breakthroughs and challenges. Res. Rep. Biochem. 2015, 5, 31-38. [CrossRef]

109. Wiersma, V.I.; van Hecke, W.; Scheper, W.; van Osch, M.A.J.; Hermsen, W.J.M.; Rozemuller, A.J.M.; Hoozemans, J.J.M. Activation of the unfolded protein response and granulovacuolar degeneration are not common features of human prion pathology. Acta Neuropathol. Commun. 2016, 4, 113. [CrossRef] [PubMed]

110. Satterfield, T.; Pritchett, J.; Cruz, S.; Kemp, K. Prion disease and endoplasmic reticulum stress pathway correlations and treatment pursuits. Endoplasmic Reticulum Stress Dis. 2017, 4, 27-36. [CrossRef]

111. Halliday, M.; Radford, H.; Mallucci, G.R. Prions: Generation and spread versus neurotoxicity. J. Biol. Chem. 2014, 289, 19862-19868. [CrossRef]

112. Jaunmuktane, Z.; Brandner, S. Invited Review: The role of prion-like mechanisms in neurodegenerative diseases. Neuropathol. Appl. Neurobiol. 2019. [CrossRef]

113. Olsson, T.T.; Klementieva, O.; Gouras, G.K. Prion-like seeding and nucleation of intracellular amyloid- $\beta$. Neurobiol. Dis. 2018, 113,1-10. [CrossRef]

114. Ye, L.; Rasmussen, J.; Kaeser, S.A.; Marzesco, A.; Obermüller, U.; Mahler, J.; Schelle, J.; Odenthal, J.; Krüger, C.; Fritschi, S.K.; et al. A $\beta$ seeding potency peaks in the early stages of cerebral $\beta$-amyloidosis. EMBO Rep. 2017, 18, 1536-1544. [CrossRef]

115. Holmes, B.B.; Furman, J.L.; Mahan, T.E.; Yamasaki, T.R.; Mirbaha, H.; Eades, W.C.; Belaygorod, L.; Cairns, N.J.; Holtzman, D.M.; Diamond, M.I. Proteopathic tau seeding predicts tauopathy in vivo. Proc. Natl. Acad. Sci. USA 2014, 111, E4376-E4385. [CrossRef] [PubMed]

116. Narasimhan, S.; Guo, J.L.; Changolkar, L.; Stieber, A.; McBride, J.D.; Silva, L.V.; He, Z.; Zhang, B.; Gathagan, R.J.; Trojanowski, J.Q.; et al. Pathological tau strains from human brains recapitulate the diversity of tauopathies in nontransgenic mouse brain. J. Neurosci. 2017, 37, 11406-11423. [CrossRef] [PubMed] 
117. Sanders, D.W.; Kaufman, S.K.; DeVos, S.L.; Sharma, A.M.; Mirbaha, H.; Li, A.; Barker, S.J.; Foley, A.C.; Thorpe, J.R.; Serpell, L.C.; et al. Distinct tau prion strains propagate in cells and mice and define different tauopathies. Neuron 2014, 82, 1271-1288. [CrossRef] [PubMed]

118. Clavaguera, F.; Akatsu, H.; Fraser, G.; Crowther, R.A.; Frank, S.; Hench, J.; Probst, A.; Winkler, D.T.; Reichwald, J.; Staufenbiel, M.; et al. Brain homogenates from human tauopathies induce tau inclusions in mouse brain. Proc. Natl. Acad. Sci. USA 2013, 110, 9535-9540. [CrossRef]

119. Kaufman, S.K.; Sanders, D.W.; Thomas, T.L.; Ruchinskas, A.J.; Vaquer-Alicea, J.; Sharma, A.M.; Miller, T.M.; Diamond, M.I. Tau Prion Strains Dictate Patterns of Cell Pathology, Progression Rate, and Regional Vulnerability In Vivo. Neuron 2016, 92, 796-812. [CrossRef]

120. Prusiner, S.B.; Woerman, A.L.; Mordes, D.A.; Watts, J.C.; Rampersaud, R.; Berry, D.B.; Patel, S.; Oehler, A.; Lowe, J.K.; Kravitz, S.N.; et al. Evidence for $\alpha$-synuclein prions causing multiple system atrophy in humans with parkinsonism. Proc. Natl. Acad. Sci. USA 2015, 112, E5308-E5317. [CrossRef]

121. French, R.L.; Grese, Z.R.; Aligireddy, H.; Dhavale, D.D.; Reeb, A.N.; Kedia, N.; Kotzbauer, P.T.; Bieschke, J.; Ayala, Y.M. Detection of TAR DNA-binding protein 43 (TDP-43) oligomers as initial intermediate species during aggregate formation. J. Biol. Chem. 2019, 294, 6696-6709. [CrossRef]

122. Fang, Y.S.; Tsai, K.J.; Chang, Y.J.; Kao, P.; Woods, R.; Kuo, P.H.; Wu, C.C.; Liao, J.Y.; Chou, S.C.; Lin, V.; et al. Full-length TDP-43 forms toxic amyloid oligomers that are present in frontotemporal lobar dementia-TDP patients. Nat. Commun. 2014, 5, 4824. [CrossRef]

123. Kao, P.F.; Chen, Y.R.; Liu, X.B.; Decarli, C.; Seeley, W.W.; Jin, L.W. Detection of TDP-43 oligomers in frontotemporal lobar degeneration-TDP. Ann. Neurol. 2015, 78, 211-221. [CrossRef]

124. Porta, S.; Xu, Y.; Restrepo, C.R.; Kwong, L.K.; Zhang, B.; Brown, H.J.; Lee, E.B.; Trojanowski, J.Q.; Lee, V.M.Y. Patient-derived frontotemporal lobar degeneration brain extracts induce formation and spreading of TDP-43 pathology in vivo. Nat. Commun. 2018, 9,1-15. [CrossRef]

125. Clavaguera, F.; Bolmont, T.; Crowther, R.A.; Abramowski, D.; Frank, S.; Probst, A.; Fraser, G.; Stalder, A.K.; Beibel, M.; Staufenbiel, M.; et al. Transmission and spreading of tauopathy in transgenic mouse brain. Nat. Cell Biol. 2009, 11, 909-913. [CrossRef] [PubMed]

126. Luk, K.C.; Kehm, V.; Carroll, J.; Zhang, B.; O’Brien, P.; Trojanowski, J.Q.; Lee, V.M.Y. Pathological $\alpha$-synuclein transmission initiates Parkinson-like neurodegeneration in nontransgenic mice. Science 2012, 338, 949-953. [CrossRef] [PubMed]

127. Watts, J.C.; Giles, K.; Oehler, A.; Middleton, L.; Dexter, D.T.; Gentleman, S.M.; DeArmond, S.J.; Prusiner, S.B. Transmission of multiple system atrophy prions to transgenic mice. Proc. Natl. Acad. Sci. USA 2013, 110, 19555-19560. [CrossRef] [PubMed]

128. Jaunmuktane, Z.; Mead, S.; Ellis, M.; Wadsworth, J.D.F.; Nicoll, A.J.; Kenny, J.; Launchbury, F.; Linehan, J.; Richard-Loendt, A.; Walker, A.S.; et al. Evidence for human transmission of amyloid- $\beta$ pathology and cerebral amyloid angiopathy. Nature 2015, 525, 247-250. [CrossRef]

129. Jaunmuktane, Z.; Quaegebeur, A.; Taipa, R.; Viana-Baptista, M.; Barbosa, R.; Koriath, C.; Sciot, R.; Mead, S.; Brandner, S. Evidence of amyloid- $\beta$ cerebral amyloid angiopathy transmission through neurosurgery. Acta Neuropathol. 2018, 135, 671-679. [CrossRef]

130. Frontzek, K.; Lutz, M.I.; Aguzzi, A.; Kovacs, G.G.; Budka, H. Amyloid- $\beta$ pathology and cerebral amyloid angiopathy are frequent in iatrogenic Creutzfeldt-Jakob disease after dural grafting. Swiss Med. Wkly. 2016, 146, w14287. [CrossRef]

131. Moreno, J.A.; Radford, H.; Peretti, D.; Steinert, J.R.; Verity, N.; Martin, M.G.; Halliday, M.; Morgan, J.; Dinsdale, D.; Ortori, C.A.; et al. Sustained translational repression by eIF2 $\alpha$-P mediates prion neurodegeneration. Nature 2012, 485, 507-511. [CrossRef]

132. Unterberger, U.; Höftberger, R.; Gelpi, E.; Flicker, H.; Budka, H.; Voigtländer, T. Endoplasmic Reticulum Stress Features Are Prominent in Alzheimer Disease but Not in Prion Diseases In Vivo. J. Neuropathol. Exp. Neurol. 2006, 65, 348-357. [CrossRef]

133. Hetz, C.; Lee, A.H.; Gonzalez-Romero, D.; Thielen, P.; Castilla, J.; Soto, C.; Glimcher, L.H. Unfolded protein response transcription factor XBP-1 does not influence prion replication or pathogenesis. Proc. Natl. Acad. Sci. USA 2008, 105, 757-762. [CrossRef]

134. Walter, P.; Ron, D. The unfolded protein response: From stress pathway to homeostatic regulation. Science 2011, 334, 1081-1086. [CrossRef] 
135. Bravo, R.; Parra, V.; Gatica, D.; Rodriguez, A.E.; Torrealba, N.; Paredes, F.; Wang, Z.V.; Zorzano, A.; Hill, J.A.; Jaimovich, E.; et al. Endoplasmic Reticulum and the Unfolded Protein Response. Dynamics and Metabolic Integration. In International Review of Cell and Molecular Biology; Elsevier: Amsterdam, The Netherlands, 2013; Volume 301, pp. 215-290.

136. Chong, W.C.; Shastri, M.D.; Eri, R. Endoplasmic reticulum stress and oxidative stress: A vicious nexus implicated in bowel disease pathophysiology. Int. J. Mol. Sci. 2017, 18, 771. [CrossRef]

137. Wojda, U.; Salinska, E.; Kuznicki, J. Calcium ions in neuronal degeneration. IUBMB Life 2008, 60, 575-590. [CrossRef] [PubMed]

138. Liu, H.; Yang, J.; Li, L.; Shi, W.; Yuan, X.; Wu, L. The Natural Occurring Compounds Targeting Endoplasmic Reticulum Stress. Evid. Based Complement. Altern. Med. 2016, 2016. [CrossRef] [PubMed]

139. Cao, S.S.; Kaufman, R.J. Endoplasmic reticulum stress and oxidative stress in cell fate decision and human disease. Antioxid. Redox Signal. 2014, 21, 396-413. [CrossRef] [PubMed]

140. Erguler, K.; Pieri, M.; Deltas, C. A mathematical model of the unfolded protein stress response reveals the decision mechanism for recovery, adaptation and apoptosis. BMC Syst. Biol. 2013, 7, 16. [CrossRef]

141. Urra, H.; Dufey, E.; Lisbona, F.; Rojas-Rivera, D.; Hetz, C. When ER stress reaches a dead end. Biochim. Biophys. Acta Mol. Cell Res. 2013, 1833, 3507-3517. [CrossRef] [PubMed]

142. Lindholm, D.; Korhonen, L.; Eriksson, O.; Kõks, S. Recent insights into the role of unfolded protein response in ER stress in health and disease. Front. Cell Dev. Biol. 2017, 5, 48. [CrossRef] [PubMed]

143. Gardner, B.M.; Pincus, D.; Gotthardt, K.; Gallagher, C.M.; Walter, P. Endoplasmic reticulum stress sensing in the unfolded protein response. Cold Spring Harb. Perspect. Biol. 2013, 5, 1-15. [CrossRef]

144. Rozpędek, W.; Pytel, D.; Nowak-Zduńczyk, A.; Lewko, D.; Wojtczak, R.; Diehl, J.A.; Majsterek, I. Breaking the DNA Damage Response via Serine/Threonine Kinase Inhibitors to Improve Cancer Treatment. Curr. Med. Chem. 2018, 26, 1425-1445. [CrossRef]

145. Zhang, K.; Kaufman, R.J. Signaling the unfolded protein response from the endoplasmic reticulum. J. Biol. Chem. 2004, 279, 25935-25938. [CrossRef]

146. Carrara, M.; Prischi, F.; Nowak, P.R.; Kopp, M.C.; Ali, M.M.U. Noncanonical binding of BiP ATPase domain to Ire1 and Perk is dissociated by unfolded protein $\mathrm{CH} 1$ to initiate ER stress signaling. Elife 2015, 4, e03522. [CrossRef] [PubMed]

147. Shen, J.; Prywes, R. Dependence of site-2 protease cleavage of ATF6 on prior site-1 protease digestion is determined by the size of the luminal domain of ATF6. J. Biol. Chem. 2004, 279, 43046-43051. [CrossRef]

148. Liu, C.L.; Li, X.; Gan, L.; He, Y.Y.; Wang, L.L.; He, K.L. High-content screening identifies inhibitors of the nuclear translocation of ATF6. Int. J. Mol. Med. 2016, 37, 407-414. [CrossRef]

149. Smith, H.L.; Mallucci, G.R. The unfolded protein response: Mechanisms and therapy of neurodegeneration. Brain 2016, 139, 2113-2121. [CrossRef] [PubMed]

150. Ma, Y.; Hendershot, L.M. The role of the unfolded protein response in tumour development: Friend or foe? Nat. Rev. Cancer 2004, 4, 966-977. [CrossRef] [PubMed]

151. Luo, B.; Lee, A.S. The critical roles of endoplasmic reticulum chaperones and unfolded protein response in tumorigenesis and anticancer therapies. Oncogene 2013, 32, 805-818. [CrossRef] [PubMed]

152. Chen, T.C.; Chan, N.; Labib, S.; Yu, J.; Cho, H.Y.; Hofman, F.M.; Schönthal, A.H. Induction of pro-apoptotic endoplasmic reticulum stress in multiple myeloma cells by NEO214, perillyl alcohol conjugated to rolipram. Int. J. Mol. Sci. 2018, 19, 277. [CrossRef]

153. Cui, W.; Li, J.; Ron, D.; Sha, B. The structure of the PERK kinase domain suggests the mechanism for its activation. Acta Crystallogr. Sect. D Biol. Crystallogr. 2011, 67, 423-428. [CrossRef]

154. Liu, Z.; Lv, Y.; Zhao, N.; Guan, G.; Wang, J. Protein kinase R-like ER kinase and its role in endoplasmic reticulum stress-decided cell fate. Cell Death Dis. 2015, 6, e1822. [CrossRef]

155. Bertolotti, A.; Zhang, Y.; Hendershot, L.M.; Harding, H.P.; Ron, D. Dynamic interaction of BiP and ER stress transducers in the unfolded-protein response. Nat. Cell Biol. 2000, 2, 326-332. [CrossRef]

156. Wang, P.; Li, J.; Sha, B. The ER stress sensor PERK luminal domain functions as a molecular chaperone to interact with misfolded proteins. Acta Crystallogr. Sect. D Struct. Biol. 2016, 72, 1290-1297. [CrossRef] [PubMed]

157. Pytel, D.; Majsterek, I.; Diehl, J.A. Tumor progression and the different faces of the PERK kinase. Oncogene 2016, 35, 1207-1215. [CrossRef] [PubMed] 
158. DuRose, J.B.; Scheuner, D.; Kaufman, R.J.; Rothblum, L.I.; Niwa, M. Phosphorylation of Eukaryotic Translation Initiation Factor 2 Coordinates rRNA Transcription and Translation Inhibition during Endoplasmic Reticulum Stress. Mol. Cell. Biol. 2009, 29, 4295-4307. [CrossRef] [PubMed]

159. Rozpedek, W.; Pytel, D.; Mucha, B.; Leszczynska, H.; Diehl, J.A.; Majsterek, I. The Role of the PERK/eIF2 $\alpha /$ ATF4/CHOP Signaling Pathway in Tumor Progression During Endoplasmic Reticulum Stress. Curr. Mol. Med. 2016, 16, 533-544. [CrossRef] [PubMed]

160. Devi, L.; Ohno, M. PERK mediates eIF2 $\alpha$ phosphorylation responsible for BACE1 elevation, CREB dysfunction and neurodegeneration in a mouse model of Alzheimer's disease. Neurobiol. Aging 2014, 35, 2272-2281. [CrossRef]

161. Fusakio, M.E.; Willy, J.A.; Wang, Y.; Mirek, E.T.; Baghdadi, R.J.T.A.; Adams, C.M.; Anthony, T.G.; Wek, R.C. Transcription factor ATF4 directs basal and stress-induced gene expression in the unfolded protein response and cholesterol metabolism in the liver. Mol. Biol. Cell 2016, 27, 1536-1551. [CrossRef]

162. Harding, H.P.; Zhang, Y.; Zeng, H.; Novoa, I.; Lu, P.D.; Calfon, M.; Sadri, N.; Yun, C.; Popko, B.; Paules, R.; et al. An integrated stress response regulates amino acid metabolism and resistance to oxidative stress. Mol. Cell 2003, 11, 619-633. [CrossRef]

163. Grek, C.; Townsend, D.M. Protein Disulfide Isomerase Superfamily in Disease and the Regulation of Apoptosis. Endoplasmic Reticulum Stress Dis. 2013, 1, 4-17. [CrossRef]

164. Devi, L.; Ohno, M. Mechanisms that lessen benefits of $\beta$-secretase reduction in a mouse model of Alzheimer's disease. Transl. Psychiatry 2013, 3, e284. [CrossRef]

165. Devi, L.; Ohno, M. Phospho-eIF2 $\alpha$ Level Is Important for Determining Abilities of BACE1 Reduction to Rescue Cholinergic Neurodegeneration and Memory Defects in 5XFAD Mice. PLoS ONE 2010, 5, e12974. [CrossRef]

166. Devi, L.; Ohno, M. Deletion of the eIF2 $\alpha$ Kinase GCN2 Fails to Rescue the Memory Decline Associated with Alzheimer's Disease. PLoS ONE 2013, 8. [CrossRef] [PubMed]

167. Sadleir, K.R.; Eimer, W.A.; Kaufman, R.J.; Osten, P.; Vassar, R. Genetic Inhibition of Phosphorylation of the Translation Initiation Factor eIF2 $\alpha$ Does Not Block A $\beta$-Dependent Elevation of BACE1 and APP Levels or Reduce Amyloid Pathology in a Mouse Model of Alzheimer's Disease. PLoS ONE 2014, 9, e101643. [CrossRef] [PubMed]

168. Hughes, D.; Mallucci, G.R. The unfolded protein response in neurodegenerative disorders-Therapeutic modulation of the PERK pathway. FEBS J. 2019, 286, 342-355. [CrossRef] [PubMed]

169. López, I.; Tournillon, A.S.; Martins, R.P.; Karakostis, K.; Malbert-Colas, L.; Nylander, K.; Fåhraeus, R. P53-mediated suppression of BiP triggers BIK-induced apoptosis during prolonged endoplasmic reticulum stress. Cell Death Differ. 2017, 24, 1717-1729. [CrossRef]

170. Pasini, S.; Corona, C.; Liu, J.; Greene, L.A.; Shelanski, M.L. Specific downregulation of hippocampal ATF4 reveals a necessary role in synaptic plasticity and memory. Cell Rep. 2015, 11, 183-191. [CrossRef]

171. Martínez, G.; Vidal, R.L.; Mardones, P.; Serrano, F.G.; Ardiles, A.O.; Wirth, C.; Valdés, P.; Thielen, P.; Schneider, B.L.; Kerr, B.; et al. Regulation of Memory Formation by the Transcription Factor XBP1. Cell Rep. 2016, 14, 1382-1394. [CrossRef]

172. Yan, R.; Vassar, R. Targeting the $\beta$ secretase BACE1 for Alzheimer's disease therapy. Lancet Neurol. 2014, 13, 319-329. [CrossRef]

173. Macleod, R.; Hillert, E.K.; Cameron, R.T.; Baillie, G.S. The role and therapeutic targeting of $\alpha$-, $\beta$-and $\gamma$-secretase in Alzheimer's disease. Future Sci. OA 2015, 1. [CrossRef]

174. Pillai, S. Birth pangs: The stressful origins of lymphocytes. J. Clin. Investig. 2005, 115, 224-227. [CrossRef]

175. Endres, K.; Reinhardt, S. ER-stress in Alzheimer's disease: Turning the scale? Am. J. Neurodegener. Dis. 2013, 2, 247-265.

176. Siwecka, N.; Rozpȩdek, W.; Pytel, D.; Wawrzynkiewicz, A.; Dziki, A.; Dziki, Ł.; Alan Diehl, J.; Majsterek, I.; Dziki, L.; Alan Diehl, J.; et al. Dual role of endoplasmic reticulum stress-mediated unfolded protein response signaling pathway in carcinogenesis. Int. J. Mol. Sci. 2019, 20, 4354. [CrossRef] [PubMed]

177. Malhotra, J.D.; Kaufman, R.J. The endoplasmic reticulum and the unfolded protein response. Semin. Cell Dev. Biol. 2007, 18, 716-731. [CrossRef] [PubMed]

178. Zinszner, H.; Kuroda, M.; Wang, X.Z.; Batchvarova, N.; Lightfoot, R.T.; Remotti, H.; Stevens, J.L.; Ron, D. $\mathrm{CHOP}$ is implicated in programmed cell death in response to impaired function of the endoplasmic reticulum. Genes Dev. 1998, 12, 982-995. [CrossRef] [PubMed] 
179. Rodriguez, D.; Rojas-Rivera, D.; Hetz, C. Integrating stress signals at the endoplasmic reticulum: The BCL-2 protein family rheostat. Biochim. Biophys. Acta Mol. Cell Res. 2011, 1813, 564-574. [CrossRef]

180. O'neill, K.L.; Huang, K.; Zhang, J.; Chen, Y.; Luo, X. Inactivation of prosurvival Bcl-2 proteins activates Bax/Bak through the outer mitochondrial membrane. Genes Dev. 2016, 30, 973-988. [CrossRef]

181. Wali, J.A.; Rondas, D.; McKenzie, M.D.; Zhao, Y.; Elkerbout, L.; Fynch, S.; Gurzov, E.N.; Akira, S.; Mathieu, C.; Kay, T.W.H.; et al. The proapoptotic BH3-only proteins Bim and Puma are downstream of endoplasmic reticulum and mitochondrial oxidative stress in pancreatic islets in response to glucotoxicity. Cell Death Dis. 2014, 5, e1124. [CrossRef]

182. Szegezdi, E.; Logue, S.E.; Gorman, A.M.; Samali, A. Mediators of endoplasmic reticulum stress-induced apoptosis. EMBO Rep. 2006, 7, 880-885. [CrossRef]

183. Galehdar, Z.; Swan, P.; Fuerth, B.; Callaghan, S.M.; Park, D.S.; Cregan, S.P. Neuronal apoptosis induced by endoplasmic reticulum stress is regulated by ATF4-CHOP-mediated induction of the Bcl-2 homology 3-only member PUMA. J. Neurosci. 2010, 30, 16938-16948. [CrossRef]

184. Bunk, E.C.; König, H.G.; Bernas, T.; Engel, T.; Henshall, D.C.; Kirby, B.P.; Prehn, J.H.M. BH3-only proteins BIM and PUMA in the regulation of survival and neuronal differentiation of newly generated cells in the adult mouse hippocampus. Cell Death Dis. 2010, 1, e15. [CrossRef]

185. Ghosh, A.P.; Klocke, B.J.; Ballestas, M.E.; Roth, K.A. CHOP potentially co-operates with FOXO3a in neuronal cells to regulate PUMA and BIM expression in response to ER stress. PLoS ONE 2012, 7, e39586. [CrossRef]

186. Kudo, W.; Lee, H.G.P.; Smith, M.A.; Zhu, X.; Matsuyama, S.; Lee, H.G.P. Inhibition of Bax protects neuronal cells from oligomeric A $\beta$ neurotoxicity. Cell Death Dis. 2012, 3, e309. [CrossRef] [PubMed]

187. Rojas, M.; Vasconcelos, G.; Dever, T.E. An eIF2 $\alpha$-binding motif in protein phosphatase 1 subunit GADD34 and its viral orthologs is required to promote dephosphorylation of eIF2 $\alpha$. Proc. Natl. Acad. Sci. USA 2015, 112, E3466-E3475. [CrossRef] [PubMed]

188. Novoa, I.; Zeng, H.; Harding, H.P.; Ron, D. Feedback inhibition of the unfolded protein response by GADD34-mediated dephosphorylation of eIF2 $\alpha$. J. Cell Biol. 2001, 153, 1011-1021. [CrossRef]

189. Hollander, M.C.; Zhan, Q.; Bae, I.; Fornace, A.J. Mammalian GADD34, an apoptosis and DNA damage-inducible gene. J. Biol. Chem. 1997, 272, 13731-13737. [CrossRef] [PubMed]

190. Adler, H.T.; Chinery, R.; Wu, D.Y.; Kussick, S.J.; Payne, J.M.; Fornace, A.J.; Tkachuk, D.C. Leukemic HRX Fusion Proteins Inhibit GADD34-Induced Apoptosis and Associate with the GADD34 and hSNF5/INI1 Proteins. Mol. Cell. Biol. 1999, 19, 7050-7060. [CrossRef] [PubMed]

191. Feldman, D.E.; Chauhan, V.; Koong, A.C. The unfolded protein response: A novel component of the hypoxic stress response in tumors. Mol. Cancer Res. 2005, 3, 597-605. [CrossRef]

192. Cornejo, V.H.; Hetz, C. The unfolded protein response in Alzheimer's disease. Semin. Immunopathol. 2013, 35, 277-292. [CrossRef]

193. Boyce, M.; Bryant, K.F.; Jousse, C.; Long, K.; Harding, H.P.; Scheuner, D.; Kaufman, R.J.; Ma, D.; Coen, D.M.; Ron, D.; et al. A selective inhibitor of elF $2 \alpha$ dephosphorylation protects cells from ER stress. Science 2005, 307, 935-939. [CrossRef]

194. Tabas, I.; Ron, D. Integrating the mechanisms of apoptosis induced by endoplasmic reticulum stress. Nat. Cell Biol. 2011, 13, 184-190. [CrossRef]

195. Kalaria, R.N. The role of cerebral ischemia in Alzheimer's disease. Neurobiol. Aging 2000, 21, 321-330. [CrossRef]

196. Lucke-Wold, B.P.; Turner, R.C.; Logsdon, A.F.; Simpkins, J.W.; Alkon, D.L.; Smith, K.E.; Chen, Y.W.; Tan, Z.; Huber, J.D.; Rosen, C.L. Common mechanisms of Alzheimer's disease and ischemic stroke: The role of protein kinase $C$ in the progression of age-related neurodegeneration. J. Alzheimer's Dis. 2015, 43, 711-724. [CrossRef] [PubMed]

197. Pluta, R.; Jabłoński, M.; Ułamek-Kozioł, M.; Kocki, J.; Brzozowska, J.; Januszewski, S.; Furmaga-Jabłońska, W.; Bogucka-Kocka, A.; Maciejewski, R.; Czuczwar, S.J. Sporadic alzheimer's disease begins as episodes of brain ischemia and ischemically dysregulated alzheimer's disease genes. Mol. Neurobiol. 2013, 48, 500-515. [CrossRef] [PubMed]

198. Tajiri, S.; Oyadomari, S.; Yano, S.; Morioka, M.; Gotoh, T.; Hamada, J.I.; Ushio, Y.; Mori, M. Ischemia-induced neuronal cell death is mediated by the endoplasmic reticulum stress pathway involving CHOP. Cell Death Differ. 2004, 11, 403-415. [CrossRef] [PubMed] 
199. Poone, G.; Hasseldam, H.; Munkholm, N.; Rasmussen, R.; Grønberg, N.; Johansen, F. The Hypothermic Influence on CHOP and Ero1- $\alpha$ in an Endoplasmic Reticulum Stress Model of Cerebral Ischemia. Brain Sci. 2015, 5, 178-187. [CrossRef]

200. Scull, C.M.; Tabas, I. Mechanisms of ER stress-induced apoptosis in atherosclerosis. Arterioscler. Thromb. Vasc. Biol. 2011, 31, 2792-2797. [CrossRef] [PubMed]

201. Zeeshan, H.M.A.; Lee, G.H.; Kim, H.R.; Chae, H.J. Endoplasmic reticulum stress and associated ROS. Int. J. Mol. Sci. 2016, 17, 327. [CrossRef]

202. Laurindo, F.R.M.; Araujo, T.L.S.; Abrahão, T.B. Nox NADPH oxidases and the endoplasmic reticulum. Antioxid. Redox Signal. 2014, 20, 2755-2775. [CrossRef]

203. Lee, D.Y.; Lee, K.-S.S.; Lee, H.J.; Kim, D.H.D.K.D.H.; Noh, Y.H.; Yu, K.; Jung, H.-Y.Y.; Lee, S.H.; Lee, J.Y.; Youn, Y.C.; et al. Activation of PERK signaling attenuates A $\beta$-mediated ER stress. PLoS ONE 2010, 5, e10489. [CrossRef]

204. Plácido, A.I.; Oliveira, C.R.; Moreira, P.I.; Pereira, C.M.F. Enhanced Amyloidogenic Processing of Amyloid Precursor Protein and Cell Death Under Prolonged Endoplasmic Reticulum Stress in Brain Endothelial Cells. Mol. Neurobiol. 2015, 51, 571-590. [CrossRef]

205. Fonseca, A.C.R.G.; Ferreiro, E.; Oliveira, C.R.; Cardoso, S.M.; Pereira, C.F. Activation of the endoplasmic reticulum stress response by the amyloid-beta 1-40 peptide in brain endothelial cells. Biochim. Biophys. Acta Mol. Basis Dis. 2013, 1832, 2191-2203. [CrossRef]

206. Chen, W.; Chan, Y.; Wan, W.; Li, Y.; Zhang, C. A $\beta 1-42$ induces cell damage via RAGE-dependent endoplasmic reticulum stress in bEnd.3 cells. Exp. Cell Res. 2018, 362, 83-89. [CrossRef] [PubMed]

207. Shen, H.; Pan, X.D.; Zhang, J.; Zeng, Y.Q.; Zhou, M.; Yang, L.M.; Ye, B.; Dai, X.M.; Zhu, Y.G.; Chen, X.C. Endoplasmic reticulum stress induces the early appearance of pro-apoptotic and anti-apoptotic proteins in neurons of five familial alzheimer's disease mice. Chin. Med. J. 2016, 129, 2845-2852. [CrossRef] [PubMed]

208. Cui, W.; Wang, S.; Wang, Z.; Wang, Z.; Sun, C.; Zhang, Y. Inhibition of PTEN Attenuates Endoplasmic Reticulum Stress and Apoptosis via Activation of PI3K/AKT Pathway in Alzheimer's Disease. Neurochem. Res. 2017, 42, 3052-3060. [CrossRef] [PubMed]

209. Alberdi, E.; Wyssenbach, A.; Alberdi, M.; Sánchez-Gómez, M.V.; Cavaliere, F.; Rodríguez, J.J.; Verkhratsky, A.; Matute, C. $\mathrm{Ca}^{2+}$ dependent endoplasmic reticulum stress correlates with astrogliosis in oligomeric amyloid $\beta$-treated astrocytes and in a model of Alzheimer's disease. Aging Cell 2013, 12, 292-302. [CrossRef] [PubMed]

210. Soejima, N.; Ohyagi, Y.; Nakamura, N.; Himeno, E.; Iinuma, M.K.; Sakae, N.; Yamasaki, R.; Tabira, T.; Murakami, K.; Irie, K.; et al. Intracellular Accumulation of Toxic Turn Amyloid- $\beta$ is Associated with Endoplasmic Reticulum Stress in Alzheimer's Disease. Curr. Alzheimer Res. 2013, 10, 11-20. [PubMed]

211. Katayama, T.; Imaizumi, K.; Sato, N.; Miyoshi, K.; Kudo, T.; Hitomi, J.; Morihara, T.; Yoneda, T.; Gomi, F.; Mori, Y.; et al. Presenilin-1 mutations downregulate the signalling pathway of the unfolded-protein response. Nat. Cell Biol. 1999, 1, 479-485. [CrossRef]

212. Ho, Y.S.; Yang, X.; Lau, J.C.F.; Hung, C.H.L.; Wuwongse, S.; Zhang, Q.; Wang, J.; Baum, L.; So, K.F.; Chang, R.C.C. Endoplasmic reticulum stress induces tau pathology and forms a vicious cycle: Implication in Alzheimer's disease pathogenesis. J. Alzheimer's Dis. 2012, 28, 839-854. [CrossRef]

213. Cheng, K.C.; Chiang, H.C. XBP1 and PERK Have Distinct Roles in A $\beta$-Induced Pathology. Mol. Neurobiol. 2018, 55, 7523-7532. [CrossRef]

214. Köhler, C.; Dinekov, M.; Götz, J. Granulovacuolar degeneration and unfolded protein response in mouse models of tauopathy and A $\beta$ amyloidosis. Neurobiol. Dis. 2014, 71, 169-179. [CrossRef]

215. Mercado, G.; Hetz, C. Drug repurposing to target proteostasis and prevent neurodegeneration: Accelerating translational efforts. Brain 2017, 140, 1544-1547. [CrossRef]

216. Ma, T.; Trinh, M.A.; Wexler, A.J.; Bourbon, C.; Gatti, E.; Pierre, P.; Cavener, D.R.; Klann, E. Suppression of eIF2 $\alpha$ kinases alleviates Alzheimer's disease-related plasticity and memory deficits. Nat. Neurosci. 2013, 16, 1299-1305. [CrossRef] [PubMed]

217. Baleriola, J.; Walker, C.A.; Jean, Y.Y.; Crary, J.F.; Troy, C.M.; Nagy, P.L.; Hengst, U. Axonally synthesized ATF4 transmits a neurodegenerative signal across brain regions. Cell 2014, 158, 1159-1172. [CrossRef] [PubMed]

218. Mamada, N.; Tanokashira, D.; Hosaka, A.; Kametani, F.; Tamaoka, A.; Araki, W. Amyloid $\beta$-protein oligomers upregulate the $\beta$-secretase, BACE1, through a post-translational mechanism involving its altered subcellular distribution in neurons. Mol. Brain 2015, 8, 73. [CrossRef] [PubMed] 
219. Segev, Y.; Barrera, I.; Ounallah-Saad, H.; Wibrand, K.; Sporild, I.; Livne, A.; Rosenberg, T.; David, O.; Mints, M.; Bramham, C.R.; et al. PKR inhibition rescues memory deficit and atf4 overexpression in apoe $\varepsilon 4$ human replacement mice. J. Neurosci. 2015, 35, 12986-12993. [CrossRef]

220. Zhong, N.; Ramaswamy, G.; Weisgraber, K.H. Apolipoprotein E4 domain interaction induces endoplasmic reticulum stress and impairs astrocyte function. J. Biol. Chem. 2009, 284, 27273-27280. [CrossRef]

221. Lee, J.H.; Won, S.M.; Suh, J.; Son, S.J.; Moon, G.J.; Park, U.J.; Gwag, B.J. Induction of the unfolded protein response and cell death pathway in alzheimer's disease, but not in aged Tg2576 mice. Exp. Mol. Med. 2010, 42, 386-394. [CrossRef]

222. Xu, N.; Xiao, Z.; Zou, T.; Huang, Z. Induction of GADD34 regulates the neurotoxicity of amyloid $\beta$. Am. J. Alzheimer's. Dis. Other Dement. 2015, 30,313-319. [CrossRef]

223. Honjo, Y.; Ayaki, T.; Tomiyama, T.; Horibe, T.; Ito, H.; Mori, H.; Takahashi, R.; Kawakami, K. Increased GADD34 in oligodendrocytes in Alzheimer's disease. Neurosci. Lett. 2015, 602, 50-55. [CrossRef]

224. Chiu, C.C.; Lu, C.S.; Weng, Y.H.; Chen, Y.L.; Huang, Y.Z.; Chen, R.S.; Cheng, Y.C.; Huang, Y.C.; Liu, Y.C.; Lai, S.C.; et al. PARK14 (D331Y) PLA2G6 Causes Early-Onset Degeneration of Substantia Nigra Dopaminergic Neurons by Inducing Mitochondrial Dysfunction, ER Stress, Mitophagy Impairment and Transcriptional Dysregulation in a Knockin Mouse Model. Mol. Neurobiol. 2019, 56, 3835-3853. [CrossRef]

225. Holtz, W.A.; O'Malley, K.L. Parkinsonian Mimetics Induce Aspects of Unfolded Protein Response in Death of Dopaminergic Neurons. J. Biol. Chem. 2003, 278, 19367-19377. [CrossRef]

226. Yamamuro, A.; Yoshioka, Y.; Ogita, K.; Maeda, S. Involvement of Endoplasmic Reticulum Stress on the Cell Death Induced by 6-Hydroxydopamine in Human Neuroblastoma SH-SY5Y Cells. Neurochem. Res. 2006, 31, 657-664. [CrossRef] [PubMed]

227. Salganik, M.; Sergeyev, V.G.; Shinde, V.; Meyers, C.A.; Gorbatyuk, M.S.; Lin, J.H.; Zolotukhin, S.; Gorbatyuk, O.S. The loss of glucose-regulated protein 78 (GRP78) during normal aging or from siRNA knockdown augments human alpha-synuclein ( $\alpha$-syn) toxicity to rat nigral neurons. Neurobiol. Aging 2015, 36, 2213-2223. [CrossRef] [PubMed]

228. Gorbatyuk, M.S.; Shabashvili, A.; Chen, W.; Meyers, C.; Sullivan, L.F.; Salganik, M.; Lin, J.H.; Lewin, A.S.; Muzyczka, N.; Gorbatyuk, O.S. Glucose regulated protein 78 diminishes $\alpha$-synuclein neurotoxicity in a rat model of parkinson disease. Mol. Ther. 2012, 20, 1327-1337. [CrossRef] [PubMed]

229. Baek, J.H.; Mamula, D.; Tingstam, B.; Pereira, M.; He, Y.; Svenningsson, P. GRP78 level is altered in the brain, but not in plasma or cerebrospinal fluid in Parkinson's disease patients. Front. Neurosci. 2019, $13,697$. [CrossRef]

230. Yang, J.; Kim, K.S.; Iyirhiaro, G.O.; Marcogliese, P.C.; Callaghan, S.M.; Qu, D.; Kim, W.J.; Slack, R.S.; Park, D.S. DJ-1 modulates the unfolded protein response and cell death via upregulation of ATF4 following ER stress. Cell Death Dis. 2019, 10,1-17. [CrossRef]

231. Mercado, G.; Castillo, V.; Soto, P.; López, N.; Axten, J.M.; Sardi, S.P.; Hoozemans, J.J.M.; Hetz, C. Targeting PERK signaling with the small molecule GSK2606414 prevents neurodegeneration in a model of Parkinson's disease. Neurobiol. Dis. 2018, 112, 136-148. [CrossRef]

232. Amodio, G.; Moltedo, O.; Fasano, D.; Zerillo, L.; Oliveti, M.; Di Pietro, P.; Faraonio, R.; Barone, P.; Pellecchia, M.T.; De Rosa, A.; et al. PERK-mediated unfolded protein response activation and oxidative stress in PARK20 fibroblasts. Front. Neurosci. 2019, 13, 673. [CrossRef]

233. Hashida, K.; Kitao, Y.; Sudo, H.; Awa, Y.; Maeda, S.; Mori, K.; Takahashi, R.; Iinuma, M.; Hori, O. ATF6alpha Promotes Astroglial Activation and Neuronal Survival in a Chronic Mouse Model of Parkinson's Disease. PLOS ONE 2012, 7, e47950. [CrossRef] [PubMed]

234. Celardo, I.; Costa, A.C.; Lehmann, S.; Jones, C.; Wood, N.; Mencacci, N.E.; Mallucci, G.R.; Loh, S.H.Y.; Martins, L.M. Mitofusin-mediated ER stress triggers neurodegeneration in pink1/parkin models of Parkinson's disease. Cell Death Dis. 2016, 7, e2271. [CrossRef]

235. Gully, J.C.; Sergeyev, V.G.; Bhootada, Y.; Mendez-Gomez, H.; Meyers, C.A.; Zolotukhin, S.; Gorbatyuk, M.S.; Gorbatyuk, O.S. Up-regulation of activating transcription factor 4 induces severe loss of dopamine nigral neurons in a rat model of Parkinson's disease. Neurosci. Lett. 2016, 627, 36-41. [CrossRef]

236. Reijonen, S.; Putkonen, N.; Nørremølle, A.; Lindholm, D.; Korhonen, L. Inhibition of endoplasmic reticulum stress counteracts neuronal cell death and protein aggregation caused by $\mathrm{N}$-terminal mutant huntingtin proteins. Exp. Cell Res. 2008, 314, 950-960. [CrossRef] [PubMed] 
237. Waelter, S.; Boeddrich, A.; Lurz, R.; Scherzinger, E.; Lueder, G.; Lehrach, H.; Wanker, E.E. Accumulation of mutant huntingtin fragments in aggresome-like inclusion bodies as a result of insufficient protein degradation. Mol. Biol. Cell 2001, 12, 1393-1407. [CrossRef] [PubMed]

238. Nishitoh, H.; Matsuzawa, A.; Tobiume, K.; Saegusa, K.; Takeda, K.; Inoue, K.; Hori, S.; Kakizuka, A.; Ichijo, H. ASK1 is essential for endoplasmic reticulum stress-induced neuronal cell death triggered by expanded polyglutamine repeats. Genes Dev. 2002, 16, 1345-1355. [CrossRef] [PubMed]

239. Lee, H.; Ahn, H.H.; Lee, W.J.; Oh, Y.; Choi, H.; Shim, S.M.; Shin, J.; Jung, Y.K. ENC1 Modulates the Aggregation and Neurotoxicity of Mutant Huntingtin Through p62 Under ER Stress. Mol. Neurobiol. 2016, 53, 6620-6634. [CrossRef] [PubMed]

240. Jiang, Y.; Lv, H.; Liao, M.; Xu, X.; Huang, S.; Tan, H.; Peng, T.; Zhang, Y.; Li, H. GRP78 counteracts cell death and protein aggregation caused by mutant huntingtin proteins. Neurosci. Lett. 2012, 516, 182-187. [CrossRef] [PubMed]

241. Lajoie, P.; Snapp, E.L. Changes in BiP availability reveal hypersensitivity to acute endoplasmic reticulum stress in cells expressing mutant huntingtin. J. Cell Sci. 2011, 124, 3332-3343. [CrossRef]

242. Leitman, J.; Barak, B.; Benyair, R.; Shenkman, M.; Ashery, U.; Hartl, F.U.; Lederkremer, G.Z. ER Stress-Induced eIF2-alpha Phosphorylation Underlies Sensitivity of Striatal Neurons to Pathogenic Huntingtin. PLoS ONE 2014, 9, e90803. [CrossRef]

243. Hyrskyluoto, A.; Bruelle, C.; Lundh, S.H.; Do, H.T.; Kivinen, J.; Rappou, E.; Reijonen, S.; Waltimo, T.; Petersén, Å.; Lindholm, D.; et al. Ubiquitin-specific protease-14 reduces cellular aggregates and protects against mutant huntingtin-induced cell degeneration: Involvement of the proteasome and ER stress-activated kinase IRE1 $\alpha$. Hum. Mol. Genet. 2014, 23, 5928-5939. [CrossRef]

244. Sbodio, J.I.; Snyder, S.H.; Paul, B.D. Transcriptional control of amino acid homeostasis is disrupted in Huntington's disease. Proc. Natl. Acad. Sci. USA 2016, 113, 8843-8848. [CrossRef]

245. Fu, Z.; Liu, F.; Liu, C.; Jin, B.; Jiang, Y.; Tang, M.; Qi, X.; Guo, X. Mutant huntingtin inhibits the mitochondrial unfolded protein response by impairing ABCB10 mRNA stability. Biochim. Biophys. Acta Mol. Basis Dis. 2019, 1865, 1428-1435. [CrossRef]

246. Hetz, C.; Castilla, J.; Soto, C. Perturbation of endoplasmic reticulum homeostasis facilitates prion replication. J. Biol. Chem. 2007, 282, 12725-12733. [CrossRef]

247. Ferreiro, E.; Costa, R.; Marques, S.; Cardoso, S.M.; Oliveira, C.R.; Pereira, C.M.F. Involvement of mitochondria in endoplasmic reticulum stress-induced apoptotic cell death pathway triggered by the prion peptide $\operatorname{PrP}_{106-126}$. J. Neurochem. 2008, 104, 766-776. [CrossRef] [PubMed]

248. Provansal, M.; Roche, S.; Pastore, M.; Casanova, D.; Belondrade, M.; Alais, S.; Leblanc, P.; Windl, O.; Lehmann, S. Proteomic consequences of expression and pathological conversion of the prion protein in inducible neuroblastoma N2a cells. Prion 2010, 4, 292-301. [CrossRef]

249. Wang, S.B.; Shi, Q.; Xu, Y.; Xie, W.L.; Zhang, J.; Tian, C.; Guo, Y.; Wang, K.; Zhang, B.Y.; Chen, C.; et al. Protein disulfide isomerase regulates endoplasmic reticulum stress and the apoptotic process during prion infection and PrP mutant-induced cytotoxicity. PLoS ONE 2012, 7. [CrossRef]

250. Tang, Y.; Xiang, W.; Terry, L.; Kretzschmar, H.A.; Windl, O. Transcriptional analysis implicates endoplasmic reticulum stress in bovine spongiform encephalopathy. PLoS ONE 2010, 5. [CrossRef] [PubMed]

251. Jin, T.; Gu, Y.; Zanusso, G.; Sy, M.S.; Kumar, A.; Cohen, M.; Gambetti, P.; Singh, N. The chaperone protein BiP binds to a mutant prion protein and mediates its degradation by the proteasome. J. Biol. Chem. 2000, 275, 38699-38704. [CrossRef] [PubMed]

252. Yoo, Y.M.; Jeung, E.B. Calbindin-D28k in the Brain Influences the Expression of Cellular Prion Protein. Oxidative Med. Cell. Longev. 2018, 2018. [CrossRef]

253. Peters, S.L.; Déry, M.A.; LeBlanc, A.C. Familial prion protein mutants inhibit Hrd1-mediated retrotranslocation of misfolded proteins by depleting misfolded protein sensor BiP. Hum. Mol. Genet. 2016, 25, 976-988. [CrossRef]

254. Moreno, J.A.; Halliday, M.; Molloy, C.; Radford, H.; Verity, N.; Axten, J.M.; Ortori, C.A.; Willis, A.E.; Fischer, P.M.; Barrett, D.A.; et al. Oral treatment targeting the unfolded protein response prevents neurodegeneration and clinical disease in prion-infected mice. Sci. Transl. Med. 2013, 5. [CrossRef]

255. Herrmann, U.S.; Sonati, T.; Falsig, J.; Reimann, R.R.; Dametto, P.; O'Connor, T. Correction: Prion Infections and Anti-PrP Antibodies Trigger Converging Neurotoxic Pathways. PLoS Pathog. 2015, 11. [CrossRef] 
256. Dametto, P.; Lakkaraju, A.K.K.; Bridel, C.; Villiger, L.; O'Connor, T.; Herrmann, U.S.; Pelczar, P.; Rülicke, T.; McHugh, D.; Adili, A.; et al. Neurodegeneration and unfolded-protein response in mice expressing a membrane-tethered flexible tail of PrP. PLOS ONE 2015, 10. [CrossRef] [PubMed]

257. Wang, X.; Shi, Q.; Xu, K.; Gao, C.; Chen, C.; Li, X.L.; Wang, G.R.; Tian, C.; Han, J.; Dong, X.P. Familial CJD associated $\operatorname{PrP}$ mutants within transmembrane region induced CTM-PrP retention in ER and Triggered apoptosis by ER stress in SH-SY5Y cells. PLoS ONE 2011, 6. [CrossRef] [PubMed]

258. Ma, T.; Klann, E. PERK: A novel therapeutic target for neurodegenerative diseases? Alzheimer's Res. Ther. 2014, 6, 30. [CrossRef] [PubMed]

259. Axten, J.M.; Medina, J.R.; Feng, Y.; Shu, A.; Romeril, S.P.; Grant, S.W.; Li, W.H.H.; Heerding, D.A.; Minthorn, E.; Mencken, T.; et al. Discovery of 7-methyl-5-(1-\{[3-(trifluoromethyl)phenyl]acetyl\}-2, 3-dihydro-1H-indol-5-yl)-7H-pyrrolo[2,3-d]pyrimidin-4-amine (GSK2606414), a potent and selective first-in-class inhibitor of protein kinase R (PKR)-like endoplasmic reticulum kinase (PERK). J. Med. Chem. 2012, 55, 7193-7207. [CrossRef]

260. Radford, H.; Moreno, J.A.; Verity, N.; Halliday, M.; Mallucci, G.R. PERK inhibition prevents tau-mediated neurodegeneration in a mouse model of frontotemporal dementia. Acta Neuropathol. 2015, 130, 633-642. [CrossRef]

261. Ounallah-Saad, H.; Sharma, V.; Edry, E.; Rosenblum, K. Genetic or pharmacological reduction of PERK enhances cortical-dependent taste learning. J. Neurosci. 2014, 34, 14624-14632. [CrossRef]

262. Zhu, S.; Henninger, K.; McGrath, B.C.; Cavener, D.R. PERK Regulates Working Memory and Protein Synthesis-Dependent Memory Flexibility. PLoS ONE 2016, 11, e0162766. [CrossRef]

263. Sharma, V.; Ounallah-Saad, H.; Chakraborty, D.; Hleihil, M.; Sood, R.; Barrera, I.; Edry, E.; Chandran, S.K.; de Leon, S.B.T.; Kaphzan, H.; et al. Local inhibition of PERK enhances memory and reverses age-related deterioration of cognitive and neuronal properties. J. Neurosci. 2018, 38, 648-658. [CrossRef]

264. Grande, V.; Ornaghi, F.; Comerio, L.; Restelli, E.; Masone, A.; Corbelli, A.; Tolomeo, D.; Capone, V.; Axten, J.M.; Laping, N.J.; et al. PERK inhibition delays neurodegeneration and improves motor function in a mouse model of Marinesco-Sjögren syndrome. Hum. Mol. Genet. 2018, 27, 2477-2489. [CrossRef]

265. Rojas-Rivera, D.; Delvaeye, T.; Roelandt, R.; Nerinckx, W.; Augustyns, K.; Vandenabeele, P.; Bertrand, M.J.M. When PERK inhibitors turn out to be new potent RIPK1 inhibitors: Critical issues on the specificity and use of GSK2606414 and GSK2656157. Cell Death Differ. 2017, 24, 1100-1110. [CrossRef]

266. Atkins, C.; Liu, Q.; Minthorn, E.; Zhang, S.Y.; Figueroa, D.J.; Moss, K.; Stanley, T.B.; Sanders, B.; Goetz, A.; Gaul, N.; et al. Characterization of a novel PERK kinase inhibitor with antitumor and antiangiogenic activity. Cancer Res. 2013, 73, 1993-2002. [CrossRef] [PubMed]

267. Huang, X.; Chen, Y.; Zhang, H.; Ma, Q.; Zhang, Y.W.; Xu, H. Salubrinal attenuates $\beta$-amyloid-induced neuronal death and microglial activation by inhibition of the NF-kB pathway. Neurobiol. Aging 2012, 33, e9-e1007. [CrossRef] [PubMed]

268. Colla, E.; Coune, P.; Liu, Y.; Pletnikova, O.; Troncoso, J.C.; Iwatsubo, T.; Schneider, B.L.; Lee, M.K. Endoplasmic reticulum stress is important for the manifestations of $\alpha$-synucleinopathy in vivo. J. Neurosci. 2012, 32, 3306-3320. [CrossRef] [PubMed]

269. Colla, E.; Jensen, P.H.; Pletnikova, O.; Troncoso, J.C.; Glabe, C.; Lee, M.K. Accumulation of toxic $\alpha$-synuclein oligomer within endoplasmic reticulum occurs in $\alpha$-synucleinopathy in vivo. J. Neurosci. 2012, 32, 3301-3305. [CrossRef]

270. Smith, W.W.; Jiang, H.; Pei, Z.; Tanaka, Y.; Morita, H.; Sawa, A.; Dawson, V.L.; Dawson, T.M.; Ross, C.A. Endoplasmic reticulum stress and mitochondrial cell death pathways mediate A53T mutant alpha-synuclein-induced toxicity. Hum. Mol. Genet. 2005, 14, 3801-3811. [CrossRef]

271. Wu, L.; Luo, N.; Zhao, H.R.; Gao, Q.; Lu, J.; Pan, Y.; Shi, J.P.; Tian, Y.Y.; Zhang, Y.D. Salubrinal protects against rotenone-induced SH-SY5Y cell death via ATF4-parkin pathway. Brain Res. 2014, 1549, 52-62. [CrossRef] [PubMed]

272. Niso-Santano, M.; Bravo-San Pedro, J.M.; Gómez-Sánchez, R.; Climent, V.; Soler, G.; Fuentes, J.M.; González-Polo, R.A. ASK1 overexpression accelerates paraquat-induced autophagy via endoplasmic reticulum stress. Toxicol. Sci. 2011, 119, 156-168. [CrossRef]

273. Yang, W.; Tiffany-Castiglioni, E.; Koh, H.C.; Son, I.H. Paraquat activates the IRE1/ASK1/JNK cascade associated with apoptosis in human neuroblastoma SH-SY5Y cells. Toxicol. Lett. 2009, 191, 203-210. [CrossRef] 
274. Kim, J.S.; Heo, R.W.; Kim, H.; Yi, C.O.; Shin, H.J.; Han, J.W.; Roh, G.S. Salubrinal, ER stress inhibitor, attenuates kainic acid-induced hippocampal cell death. J. Neural Transm. 2014, 121, 1233-1243. [CrossRef]

275. Sidrauski, C.; Acosta-Alvear, D.; Khoutorsky, A.; Vedantham, P.; Hearn, B.R.; Li, H.; Gamache, K.; Gallagher, C.M.; Ang, K.K.H.; Wilson, C.; et al. Pharmacological brake-release of mRNA translation enhances cognitive memory. Elife 2013, 2, e00498. [CrossRef]

276. Sidrauski, C.; McGeachy, A.M.; Ingolia, N.T.; Walter, P. The small molecule ISRIB reverses the effects of eIF2 $\alpha$ phosphorylation on translation and stress granule assembly. Elife 2015, 4, e05033. [CrossRef] [PubMed]

277. Halliday, M.; Radford, H.; Sekine, Y.; Moreno, J.; Verity, N.; Le Quesne, J.; Ortori, C.A.; Barrett, D.A.; Fromont, C.; Fischer, P.M.; et al. Partial restoration of protein synthesis rates by the small molecule ISRIB prevents neurodegeneration without pancreatic toxicity. Cell Death Dis. 2015, 6, e1672. [CrossRef] [PubMed]

278. Hosoi, T.; Kakimoto, M.; Tanaka, K.; Nomura, J.; Ozawa, K. Unique pharmacological property of ISRIB in inhibition of A $\beta$-induced neuronal cell death. J. Pharmacol. Sci. 2016, 131, 292-295. [CrossRef] [PubMed]

279. Halliday, M.; Radford, H.; Zents, K.A.M.; Molloy, C.; Moreno, J.A.; Verity, N.C.; Smith, E.; Ortori, C.A.; Barrett, D.A.; Bushell, M.; et al. Repurposed drugs targeting eIF2 $\alpha$-P-mediated translational repression prevent neurodegeneration in mice. Brain 2017, 140, 1768-1783. [CrossRef]

280. Tsaytler, P.; Harding, H.P.; Ron, D.; Bertolotti, A. Selective inhibition of a regulatory subunit of protein phosphatase 1 restores proteostasis. Science 2011, 332, 91-94. [CrossRef]

281. Wang, L.; Popko, B.; Tixier, E.; Roos, R.P. Guanabenz, which enhances the unfolded protein response, ameliorates mutant SOD1-induced amyotrophic lateral sclerosis. Neurobiol. Dis. 2014, 71, 317-324. [CrossRef]

282. Holmes, B.; Brogden, R.N.; Heel, R.C.; Speight, T.M.; Avery, G.S. Guanabenz: A Review of its Pharmacodynamic Properties and Therapeutic Efficacy in Hypertension. Drugs 1983, 26, 212-229. [CrossRef]

283. McMahon, F.G.; Ryan, J.R.; Jain, A.K.; Vargas, R.; Vanov, S.K. Guanabenz in essential hypertension. Clin. Pharmacol. Ther. 1977, 21, 272-277. [CrossRef]

284. Das, I.; Krzyzosiak, A.; Schneider, K.; Wrabetz, L.; D’Antonio, M.; Barry, N.; Sigurdardottir, A.; Bertolotti, A. Preventing proteostasis diseases by selective inhibition of a phosphatase regulatory subunit. Science 2015, 348, 239-242. [CrossRef]

285. Crespillo-Casado, A.; Chambers, J.E.; Fischer, P.M.; Marciniak, S.J.; Ron, D. PPP1R15A-mediated dephosphorylation of eIF2a is unaffected by sephin1 or guanabenz. Elife 2017, 6, e26109. [CrossRef]

286. Li, J.L. Trazodone. In The Essence of Analgesia and Analgesics; Cambridge University Press: Cambridge, UK, 2010; pp. 351-353. ISBN 9780511841378.

287. Fagiolini, A.; Comandini, A.; Dell'Osso, M.C.; Kasper, S. Rediscovering trazodone for the treatment of major depressive disorder. CNS Drugs 2012, 26, 1033-1049. [CrossRef] [PubMed]

288. Khouzam, H.R. A review of trazodone use in psychiatric and medical conditions. Postgrad. Med. 2017, 129, 140-148. [CrossRef] [PubMed]

289. Rozpędek, W.; Pytel, D.; Popławski, T.; Walczak, A.; Gradzik, K.; Wawrzynkiewicz, A.; Wojtczak, R.; Mucha, B.; Diehl, J.A.; Majsterek, I. Inhibition of the PERK-dependent unfolded protein response signaling pathway involved in the pathogenesis of Alzheimer's disease. Curr. Alzheimer Res. 2019, 16, $209-218$. [CrossRef] [PubMed]

290. Chao, J.; Yu, M.S.; Ho, Y.S.; Wang, M.; Chang, R.C.C. Dietary oxyresveratrol prevents parkinsonian mimetic 6-hydroxydopamine neurotoxicity. Free Radic. Biol. Med. 2008, 45, 1019-1026. [CrossRef]

291. Choi, B.; Kim, S.; Jang, B.G.; Kim, M.J. Piceatannol, a natural analogue of resveratrol, effectively reduces beta-amyloid levels via activation of alpha-secretase and matrix metalloproteinase-9. J. Funct. Foods 2016, 23, 124-134. [CrossRef]

292. Sangsen, Y.; Sooksawate, T.; Likhitwitayawuid, K.; Sritularak, B.; Wiwattanapatapee, R. A Self-Microemulsifying Formulation of Oxyresveratrol Prevents Amyloid Beta Protein-Induced Neurodegeneration in Mice. Planta Med. 2018, 84, 820-828. [CrossRef]

293. Hyo, J.K.; Ki, W.L.; Hyong, J.L. Protective effects of piceatannol against beta-amyloid-induced neuronal cell death. Annals of the New York Academy of Sciences; Blackwell Publishing Inc.: Hoboken, NJ, USA, 2007; Volume 1095, pp. 473-482.

294. Temsamani, H.; Krisa, S.; Decossas-Mendoza, M.; Lambert, O.; Mérillon, J.M.; Richard, T. Piceatannol and other wine stilbenes: A pool of inhibitors against $\alpha$-synuclein aggregation and cytotoxicity. Nutrients 2016, 8 , 367. [CrossRef] 
295. Shah, A.; Chao, J.; Legido-Quigley, C.; Chang, R.C.C. Oxyresveratrol exerts ATF4-and Grp78-mediated neuroprotection against endoplasmic reticulum stress in experimental Parkinson's disease. Nutr. Neurosci. 2019, 1-16. [CrossRef]

296. Yang, Y.; Xuan, L.; Chen, H.; Dai, S.; Ji, L.; Bao, Y.; Li, C. Neuroprotective Effects and Mechanism of $\beta$ -Asarone against A $\beta$ 1-42-Induced Injury in Astrocytes. Evid. Based Complement. Altern. Med. 2017, 2017, 8516518. [CrossRef]

297. Li, Q.; Xu, F.; Zhang, Q.; Li, X.; Guo, M.; Zhang, Y.; Wang, Z.; Wang, J.; Zhao, J.; Tian, Y.; et al. Effect of $\alpha$-asarone on ethanol-induced learning and memory impairment in mice and its underlying mechanism. Life Sci. 2019, 238, 116898. [CrossRef]

298. Chen, Y.; Gao, X.; Liu, Q.; Zeng, L.; Zhang, K.; Mu, K.; Zhang, D.; Zou, H.; Wu, N.; Ou, J.; et al. Alpha-asarone improves cognitive function of aged rats by alleviating neuronal excitotoxicity via GABAA receptors. Neuropharmacology 2020, 162, 107843. [CrossRef] [PubMed]

299. Lee, J.S.E.; Kim, N.; Yeo, J.Y.; Seo, D.G.; Kim, S.; Lee, J.S.E.; Hwang, K.W.; Park, S.Y. Anti-amyloidogenic effects of asarone derivatives from perilla frutescens leaves against beta-amyloid aggregation and nitric oxide production. Molecules 2019, 24, 4297. [CrossRef]

300. Ning, B.; Deng, M.; Zhang, Q.; Wang, N.; Fang, Y. $\beta$-Asarone Inhibits IRE1/XBP1 Endoplasmic Reticulum Stress Pathway in 6-OHDA-Induced Parkinsonian Rats. Neurochem. Res. 2016, 41, 2097-2101. [CrossRef] [PubMed]

301. Ning, B.; Zhang, Q.; Wang, N.; Deng, M.; Fang, Y. $\beta$-Asarone Regulates ER Stress and Autophagy Via Inhibition of the PERK/CHOP/Bcl-2/Beclin-1 Pathway in 6-OHDA-Induced Parkinsonian Rats. Neurochem. Res. 2019, 44, 1159-1166. [CrossRef] [PubMed]

302. Zhang, J.S.; Zhou, S.F.; Wang, Q.; Guo, J.N.; Liang, H.M.; Deng, J.B.; He, W.Y. Gastrodin suppresses BACE1 expression under oxidative stress condition via inhibition of the PKR/eIF2 $\alpha$ pathway in Alzheimer's disease. Neuroscience 2016, 325, 1-9. [CrossRef]

303. Lee, G.H.; Kim, H.R.; Han, S.Y.; Bhandary, B.; Kim, D.S.; Kim, M.G.; So, B.O.; Kim, S.Y.; Jo, K.S.; Lee, B.H.; et al. Gastrodia elata blume and its pure compounds protect BV-2 microglial-derived cell lines against $\beta$-amyloid: The involvement of GRP78 and CHOP. Biol. Res. 2012, 45, 403-410.

304. Mou, Z.; Yuan, Y.H.; Lou, Y.X.; Heng, Y.; Huang, J.Y.; Xia, C.Y.; Gao, Y.; Zhu, C.G.; Chu, S.F.; Luo, P.; et al. Bibenzyl compound 20c protects against endoplasmic reticulum stress in tunicamycin-treated PC12 cells in vitro. Acta Pharmacol. Sin. 2016, 37, 1525-1533. [CrossRef] [PubMed]

305. Huang, J.Y.; Yuan, Y.H.; Yan, J.Q.; Wang, Y.N.; Chu, S.F.; Zhu, C.G.; Guo, Q.L.; Shi, J.G.; Chen, N.H. 20C, a bibenzyl compound isolated from Gastrodia elata, protects PC12 cells against rotenone-induced apoptosis via activation of the Nrf2/ARE/HO-1 signaling pathway. Acta Pharmacol. Sin. 2016, 37, 731-740. [CrossRef] 